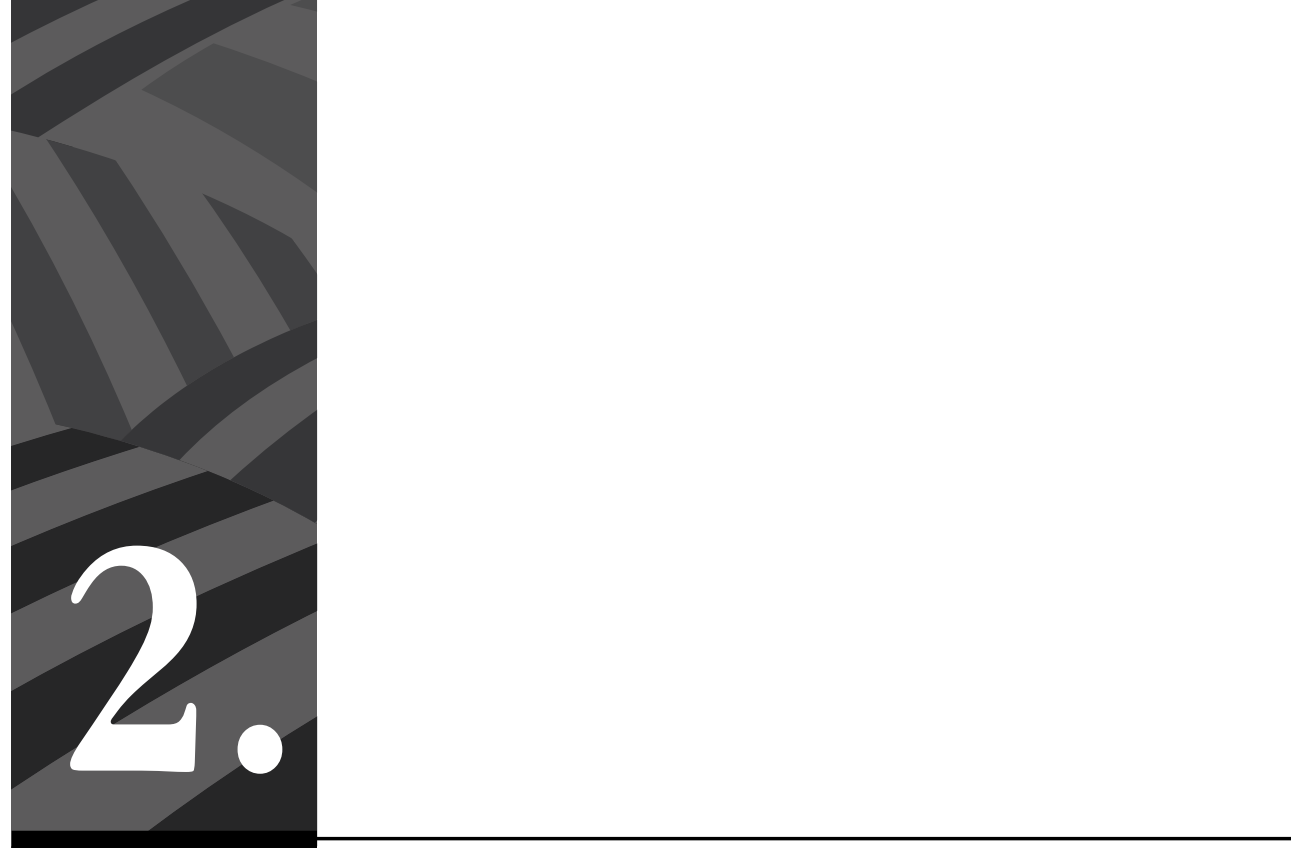

¿Autocastigo o cuerpos en resistencia? Luchas en y por la periferia de la ciudad 


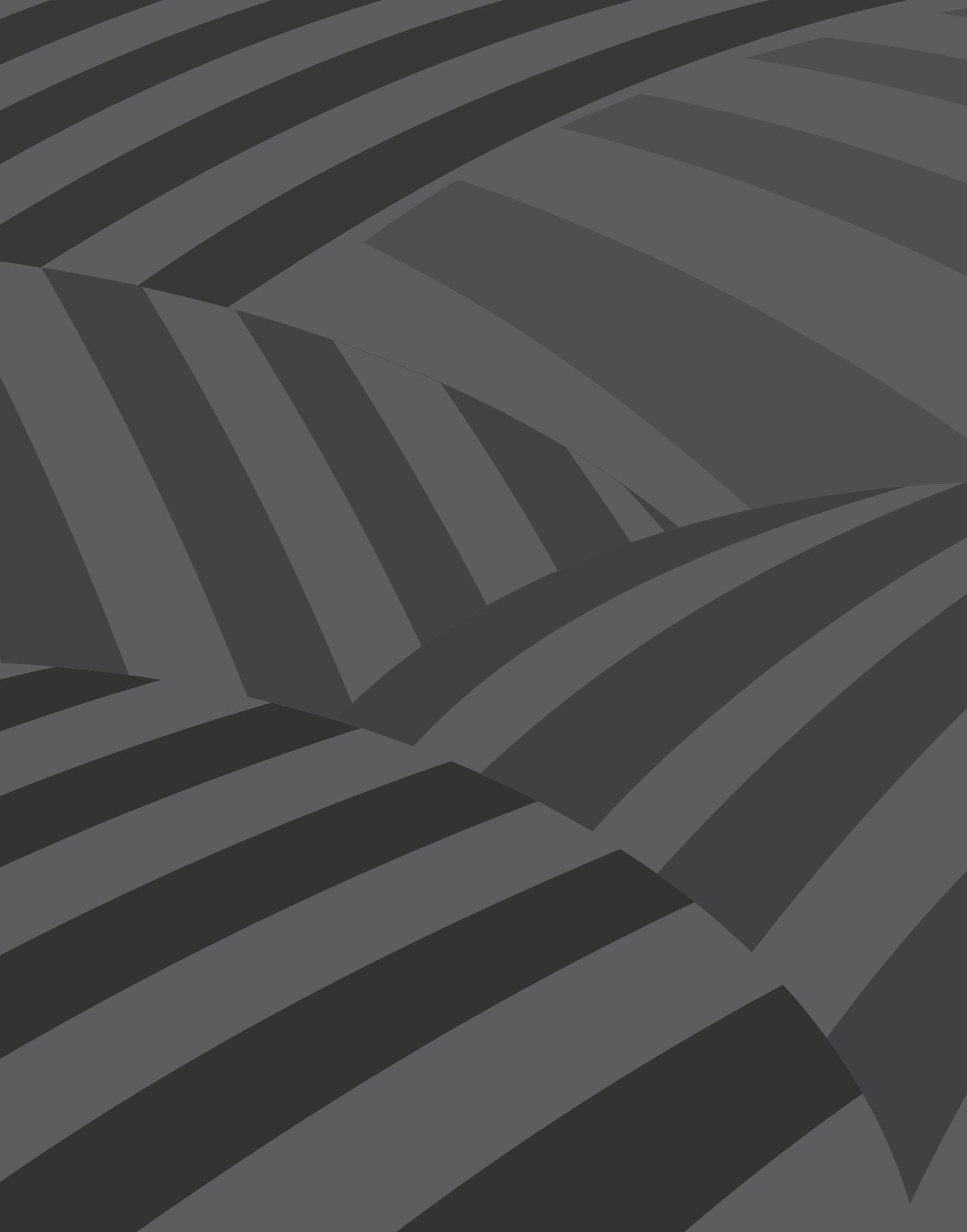




\title{
¿Autocastigo o cuerpos en resistencia? Luchas en y por la periferia de la ciudad
}

\author{
Por Martha Cecilia García Velandia*
}

Resumen: Este artículo analiza las protestas sociales que fueron acompañadas de acciones performáticas con rasgos religiosos que implicaron violencias corporales autoinfligidas, como actos de rebeldía en los que se usa el cuerpo como «hecho político» atravesado por un interés colectivo de cambio. Los protagonistas de estas acciones fueron pobladores periurbanos que develaron sus malestares ante la manera como la urbe, Bogotá, se expandió sobre sus contornos rurales, en un proceso que no ha estado exento de violencias en su pretensión de imponer la urbanidad -léase civilización, modernización, industrialización y progreso- sobre el espacio, los actores y las interacciones rurales, y tender mantos de olvido sobre la rurbanización y la bidireccionalidad de estos procesos.

Palabras clave: protestas sociales, participación extrainstitucional, violencias corporales, expansión urbana.

\section{Self Punishment or Bodies in Resistance? Struggles in and for the City's Periphery}

Abstract: This article analyzes social protests involving performative actions with religious features, such as self-inflicted bodily violence, as acts of rebellion in which the body is used as a "political fact" crossed by a collective interest of change. The protagonists of these actions were peri-urban residents who evidenced their discomfort with the city, Bogotá, and how it expanded over its rural surroundings. In fact, the imposition of urbanity—be it civilization, modernization, industrialization or progress - has not been free of violence over the space, actors, and rural interactions, nor has been the imposition of oblivion on the bidirectionality of the rurbanization process.

Keywords: social protests, extra-institutional participation, bodily violences, urban expansion.

* Socióloga, magíster en urbanismo. Miembro del equipo de Movimientos Sociales del Cinep. Agradezco a mis compañeros y a mi compañera del Equipo de Movimientos Sociales sus siempre bienvenidas críticas y sugerencias y a mis evaluadores por haberme propuesto profundizar algunas ideas esbozadas en la primera versión del artículo. Las citas de periódicos que no tienen referencia específica en este artículo fueron tomadas del archivo de prensa del Cinep. 
Cómo citar este artículo: García Velandia, Martha Cecilia (2019). ¿Autocastigo o cuerpos en resistencia? Luchas en y por la periferia de la ciudad. Revista Controversia, 213, 55-100.

Fecha de recepción: 29 de marzo de 2019

Fecha de aprobación: 21 de mayo de 2019

\section{Introducción}

$\mathrm{E}$ ste artículo se refiere a algunas protestas protagonizadas por pobladores de la frontera urbano-rural ${ }^{1}$, o habitantes periurbanos, con el objetivo de manifestar tanto su inconformidad contra los procesos de expansión urbana que asediaban y fagocitaban su entorno rural como sus sentimientos de exclusión ante la expoliación urbana, aquella ausencia o precariedad de los servicios de consumo colectivo que, con el acceso a la tierra y a la habitación ${ }^{2}$, son socialmente necesarios para la reproducción urbana.

Los pobladores de la frontera urbano-rural, tras el reconocimiento de que sus condiciones de vida eran precarias frente a las que vivían otros sectores sociales y el descubrimiento de la segregación socioespacial, de las diferencias intraurbanas y de la expoliación urbana a la que estaban siendo sometidos, recurrieron a repertorios de acción como movilizaciones, bloqueos de vías, tomas de espacios colectivos y huelgas de hambre. La esperanza de nuevas posibilidades de cambio dio lugar a los sentimientos, razones e intereses que los llevaron a estas las luchas, acompañadas con acciones performáticas, con ribetes religiosos,

1 Categoría acuñada en la Base de Datos de Luchas Sociales (BDLS) del Cinep como una noción que desafía la tradicional oposición urbano-rural y tiene en cuenta aspectos socioculturales, que permiten abordar factores subjetivos que intervienen en el arraigo de prácticas, saberes, identidades y modos de resolver su existencia y en la construcción de territorialidades en disputa entre la ciudad y el campo.

2 Su negación, según el sociólogo brasileño Lucio Kowarick (1991), constituye injusticia, indignidad o inmoralidad y puede generar un «sentimiento colectivo de legitimidad en su reivindicación» (p. 86). 
durante las cuales algunos manifestantes acudieron a la violencia corporal autoinfligida.

La autoinflicción de dolor en medio de una protesta social es un recurso extremo que ha sido utilizado por diversos actores sociales que esgrimen variados motivos en distintas circunstancias y localizaciones ${ }^{3}$. Sin embargo, las luchas escogidas ${ }^{4}$ resultan excepcionales en relación con otros procesos de rurbanización acaecidos en Bogotá, por estar estrechamente ligadas con procesos de poblamiento — con su carga de oficios y saberes, sistemas de producción, sus redes culturales y comerciales, conflictos y tensiones entre grupos-, de «incorporación» a la ciudad - muy distintos a los ocurridos en otros de sus bordes- y, por ende, de construcción de memorias de resistencia y lucha a nivel local.

\section{Cuerpos que sufren de manera pública, cuerpos como sitios de denuncia ${ }^{5}$}

En la tarde del miércoles 5 de julio de 1995, el matarife, sudoroso y resoplando, irrumpió en la sede de la Junta Administradora Local de Usme. Venía con sus labios cosidos, traía cadenas, un tablón burdo, un mazo y un enorme clavo. Puso la tabla sobre el escritorio de uno de los tres ediles presentes en la sala y con un diestro ademán clavó su mano derecha en ella ante la mirada atónita de varios espectadores. Se encadenó a la mesa y transido de dolor escribió con su mano izquierda:

3 Como se evidencia en la información provista, a manera de muestra, en el anexo 1.

4 Que tuvieron asiento en la localidad de Usme, al suroriente de Bogotá, donde, según la BDLS del Cinep, entre 1975 y 2018 se registraron 43 luchas, motivadas por la carencia de servicios públicos y sociales (la mitad), por afectaciones ambientales por la vecindad del basurero de la ciudad, por la falta de vivienda, de legalización de barrios y de accesos viales, por la violencia sexual contra infantes y por el conflicto armado.

5 Como evocación al investigador teatral mexicano Antonio Prieto Stambaugh (2011). 
Quiero que me ayuden para que el presidente Zanper se entere de nuestra situación. Yo estoy apostando mi vida en favor de la promesa que Sanper nos hiso cuando vino a Usme. Yo lideré la jente en la canpaña para Zanper, por eso hoy estoy poniendo el pecho. Tengo 34 años. Soy casado. Tengo 7 hijos. Soy natural de Chía ${ }^{6}$. Mi nombre es Edgar Fernando (...). (El Tiempo, 8 de julio de 1995)

Tras 26 horas y media de permanencia en la JAL, acompañado por otros matarifes, por ediles, representantes de la Defensoría del Pueblo y funcionarios de la Secretaría Distrital de Salud, permitió que médicos de esta entidad lo desclavaran y lo remitieran al hospital local?

Mediante un suplicio próximo a la crucifixión como forma de ejecución lenta, dolorosa y pública, Edgar Fernando protestó por el sellamiento de los mataderos de Usme, ordenado quince días atrás por la Secretaría Distrital de Salud (SDS) y el Departamento Administrativo de Ambiente (DAMA). Dichas entidades estimaron que estos no cumplían con las condiciones higiénico-sanitarias ni locativas exigidas para su funcionamiento: estaban dentro del perímetro urbano y en zona residencial ${ }^{8}$, no tenían sistema de tratamiento de aguas residuales y el sacrificio del ganado se hacía en el piso.

6 Al parecer, este matarife es oriundo de Chipaque, municipio que colinda con Usme y del cual quiso ser concejal a principios del 2000, según me narró un líder comunal de esa localidad, a quien entrevisté el 18 de febrero de 2019. Es probable que el error se hubiese cometido al momento de transcribir su nota.

7 «El suplicio de la crucifixión era el más horrible por la prolongación de la pena y los dolores físicos que iban en aumento (...) Los crucificados vivían toda la noche del día de la ejecución y aún todo el día siguiente, incluso hay ejemplos de haber vivido hasta el tercer día» (Sigaut, 1992, p. 107).

8 Una de las normas invocadas para expulsar a los mataderos del casco urbano fue el Estatuto de Ordenamiento Físico de Bogotá (Acuerdo 6 de 1990, derogado en 2000), que en el artículo 333 ordenaba trasladar a zonas industriales o a áreas rurales aquellas industrias o actividades que pudieran causar deterioro ambiental o impactos de otra índole o cuando se calificaran como actividades contaminantes. 
Al conocer de la protesta, la sDs reiteró que no permitiría la reapertura de los mataderos, porque la manipulación de productos de consumo humano sin precauciones representaba un alto riesgo epidemiológico para consumidores y operadores, no garantizaba la calidad ni la inocuidad de la carne y contaminaba el medio ambiente con fétidos olores y residuos sólidos y líquidos. Los mataderos debían trasladarse fuera del casco urbano, obtener la aprobación de Planeación Distrital y superar las deficiencias encontradas.

El 26 de febrero del año siguiente, este mismo carnicero se encasquetó una corona de espinas, volvió a coser su boca y a clavar, esta vez, ambas manos a una tabla, simbolizando la pasión de Cristo. Lo mismo hizo Miguel, su socio, y, acompañados de ochenta personas, se tomaron durante varias horas la iglesia de San Francisco de Asís de Usme. Los dos crucificados y quince personas más pasaron allí la noche.

Me cortaron el teléfono, debo arriendo y no he podido meter al colegio a mis hijos porque no tengo con qué (...) Hace como un mes decidí que me iba a encadenar, a poner corona de espinas y a coser la boca, porque de otra manera las autoridades distritales no nos iban a escuchar. No le dije nada a mi familia para no angustiarla y el fin de semana escogí el día y la hora en la que empezaría mi solicitud. Así que el lunes, acompañado por unas 200 personas, me vine a la iglesia de San Francisco de Asís porque aquí los medios sí me iban a poner atención. Sigilosamente entramos en la iglesia y bajo la sombra que me hicieron mis acompañantes nos amarramos a la silla y empezamos la protesta. (El Tiempo, 27 de febrero de 1996)

Los manifestantes exigían a las entidades distrital y nacional de salud que revocaran el cierre de los mataderos, porque sus propietarios los habían readecuado en el último semestre, a fin de poder dejar de lado el traslado. Así mismo, denunciaron que unas 1500 personas que trabajaban en el negocio de la carne estaban al borde de la quiebra por tan injusta clausura. 
Al día siguiente de la toma de la iglesia, la SDS corroboró que el matadero de la Asociación de Carniceros de Usme (Asodecar) no podía funcionar; sin embargo, al tener en cuenta que los propietarios le habían inyectado una millonaria inversión, decidió hacer unas pruebas durante quince días para saber si podía operar sin producir afectaciones durante un año. El objetivo de la SDS era que los dueños recuperaran la inversión y, con ese dinero, pudieran trasladarse al matadero de primera categoría ${ }^{9}$ que ya se había empezado a construir a 5 kilómetros del casco urbano de Usme, con mejores condiciones que las del matadero de cuarta que utilizaba la Asociación.

Durante los siete meses que transcurrieron entre una y otra protesta, los carniceros estuvieron matando reses en donde podían —según lo reconoció Edgar-, «en los patios de la casa, en los baños o en los potreros, porque había que subsistir de algo. Pero trabajar así no dejaba ganancias y todo el tiempo estábamos trabajando a pérdidas» (El Tiempo, 28 de febrero de 1996). "Lo mejor sería que abrieran el matadero porque aquí las condiciones de trabajo son muy precarias, no hay las mínimas condiciones de higiene, pero es que no tenemos más en donde hacerlo», dijo un hombre que llevaba más de 40 años ejerciendo el oficio de matarife en Usme (Insignares, 1996).

Planeación Distrital y la Secretaría de Salud ratificaron que Asodecar no podría funcionar por razones urbanísticas y sanitarias. La Asociación nunca había solicitado licencia de construcción ni sanitaria, por lo

9 El Decreto 1036 de 1991 (vigente hasta 2007) clasificó los mataderos de bovinos y porcinos en cinco categorías que iban de primera a cuarta más los Mínimos, según su capacidad de sacrificio y disponibilidades técnicas y de dotación: desde 320 reses y 240 cerdos (en adelante), a dos reses y dos cerdos, en turnos de ocho horas. La carne procedente de los mataderos clases 3 y 4 y de los Mínimos solo podía comercializarse dentro de la jurisdicción de la localidad donde estuviera situado el matadero. A su vez, el Decreto 2278 de 1982 determinó que los mataderos se localizarían suficientemente alejados de industrias, actividades o lugares que produjeran olores desagradables o cualquier otro tipo de contaminación, aislados de focos de insalubridad y separados convenientemente de conjuntos de viviendas. 
tanto, ese matadero no estaba autorizado ni reconocido y estaba ubicado en una zona catalogada como área suburbana de expansión, sector en donde únicamente se permitían usos agrícolas. Además, las labores de sacrificio, transporte y distribución de ganado se desarrollaban en condiciones sanitarias precarias. Como alternativa, el Distrito propuso a los matarifes que se organizaran para construir un matadero municipal técnicamente moderno, ambientalmente sano y sanitariamente aceptable (El Tiempo, 3 de marzo de 1996).

El 28 de marzo, la entrada de Usme amaneció bloqueada con un camión que fue atravesado por personas vinculadas al negocio de la carne, para expresar su inconformidad porque no había sido reabierto el matadero que estaba dentro del pueblo. Denunciaban que la Administración Distrital había incumplido el acuerdo celebrado un mes atrás para poner fin a la protesta anterior, que permitía que el matadero se reabriera. El alcalde de Usme aseguró que eso era falso y que en el acta se estableció que debían construir uno en las afueras de la ciudad (El Tiempo, 29 de marzo de 1996).

Seis años después, el lunes 3 de junio de 2002, seis líderes cívicos se tomaron la capilla a medio construir del barrio El Bosque de Usme - hoy conocida como la Iglesia Monte de Galilea-, abrieron seis hoyos en la tierra de más de un metro de profundidad, se introdujeron en ellos, pidieron que los taparan hasta el cuello y se declararon en huelga de hambre $^{10}$. Solo uno permaneció cuatro días enterrado, Edgar Fernando, el matarife. Los demás fueron reemplazados por otros voluntarios, hasta

10 El historiador y sociólogo José Manuel Jaramillo describe de manera detallada fotografías que acompañaron el registro de prensa de esta misma noticia en la introducción de un artículo sobre carencias básicas en ciudades con índices significativos de urbanización informal. Jaramillo (2003) asume esta simbólica protesta como muestra de las relaciones problemáticas que caracterizan los procesos de integración urbana de zonas periféricas (p. 148). Por su parte, el artista José Alejandro Restrepo (2011) alude a este autoentierro en un par de fotografías ubicadas en la sección dedicada a la cabeza de su libro Cuerpo gramatical. Cuerpo, arte y violencia (pp. 61 y 65). 
completar doce personas enterradas, entre las que se contaron dos mujeres y tres estudiantes. Los representantes de 61 juntas de acción comunal de la localidad permanecieron día y noche al lado de sus compañeros (El Tiempo, 12 de junio de 2002). Protestaban por la marginalidad en la que permanecían más de quince barrios de la denominada periferia sur de Bogotá: El Bosque y otros más ubicados en el borde oriental de la vía al Llano.

Figura 1. Se entierran y ayunan en protesta por la marginalidad.

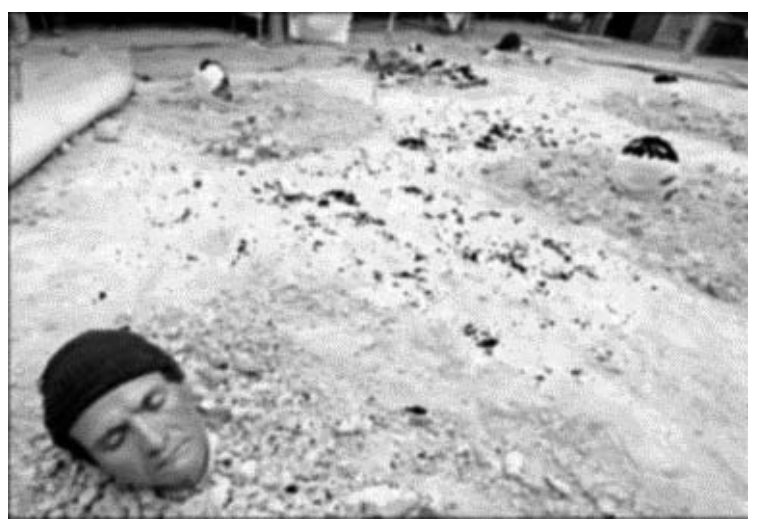

Fuente: Red 21.

«Sé que puedo morir, pero voy hasta el final, lo hago por mi familia y mi comunidad», dijo uno de los manifestantes que cubría su rostro con un pasamontañas (El Tiempo, 13 de junio de 2002). «Se agotaron las fórmulas para que las autoridades arreglen este marginado sector. Por eso, iniciamos una huelga de hambre por tiempo indefinido», expresó uno de los participantes en la protesta (La Red 21, 13 de junio de 2002). En apoyo a lo anterior, un estudiante universitario que se sumó a la protesta aseguró al mismo medio:

No podemos seguir permitiendo que toda la ciudad tenga agua potable mientras nosotros bebemos un líquido en malas condiciones (...) lo que llega a nuestras casas por el grifo es barro, eso es perjudicial para nuestros 
hijos y ha causado enfermedades en muchos de ellos. Además, aquí no hay salud, no hay educación pública, no hay vías de acceso y... ¡vivimos en Bogotá, la capital!

«Reclamamos salud, un nuevo hospital capaz de atender a la comunidad, restauración del sistema del Sisben a través de una oficina local, presupuesto para la educación nocturna, pues quieren acabarlo, pero, sobre todo, empleo, porque nos estamos muriendo de hambre», manifestó uno de los aspirantes a ser enterrado, mientras esperaba su turno. Así mismo, reclamaba una de las mujeres que se autosepultó: «Lo que quiero es que no cobren tarifas tan altas de servicios de agua, luz y teléfono, pues son estrato uno y no tienen con qué pagar» ( $\mathrm{La} \mathrm{Voz}, 19$ de junio de 2002).

También pedían la instalación de alcantarillado, la legalización por parte de Planeación Distrital de los terrenos donde funcionaba la iglesia (El Tiempo, 13 de junio de 2002) y:

Que no nos cambien el alcalde local cada cuatro meses, para que haya continuidad en la ejecución de obras... y que se monten las microempresas ofrecidas por [Andrés] Pastrana, es decir, que se cumplan las promesas que vinieron a hacer en campaña política. (El Colombiano, 16 de junio de 2002)

El alcalde mayor de Bogotá, Antanas Mockus (2007), aseveró que algunas obras solicitadas se realizarían pronto, pero no se podían alterar las prioridades que, para ese momento, eran otras. Señaló que las carencias del barrio El Bosque eran las mismas de muchos de los sectores populares de Bogotá y podían ser resueltas directamente por las autoridades locales; agregó que algunas ya habían sido atendidas, como la biblioteca pública, y otras no eran viables, como la construcción de la capilla, debido a que estaba proyectada en un lugar geológicamente imposible ${ }^{11}$ (p. 247).

11 No obstante, en 2018, fue consagrado el nuevo templo de la parroquia el Señor del Monte de Galilea durante una ceremonia presidida por el arzobispo de Bogotá, cardenal Rubén Salazar, en la que participaron «expectantes y alegres, los habitantes del barrio El Bosque de la localidad de Usme (...). Después de varios años de lucha incansable se logró construir un espacio digno, adecuado y cómodo para todos los fieles del sector» (El Catolicismo, 22 de octubre de 2018). 
Una semana después de esa protesta, Mockus anunció una donación de la Unión Europea de un monto significativo de euros para obras de infraestructura en Usme, que beneficiaría a cerca de 18 barrios donde la mayoría de pobladores vivía en la pobreza extrema. Según el alcalde, los recursos se empezaron a gestionar un año y medio atrás, después de que la comunidad priorizó en los Encuentros Ciudadanos los proyectos para dotar a estos barrios de mejores servicios públicos, de salud y educación, vías de acceso y vivienda. Finalmente, advirtió «Ahora no vayan a decir que fue por la huelga que se consiguieron los recursos para colmar sus reclamos, porque la solución se estaba buscando desde el año pasado» (El Tiempo, 14 de junio de 2002).

En estas tres protestas los protagonistas, pobladores de frontera urbanorural, adelantaron acciones performáticas ${ }^{12}$ —es decir, que incluyeron elementos teatrales - con rasgos religiosos que implicaron violencias corporales autoinfligidas como coserse los labios, coronarse de espinas, crucificarse, ayunar o enterrarse vivos ${ }^{13}$. Dichos actos son rituales «sacrificiales», como los denomina el antropólogo mexicano Francisco Cruces, que encarnan una cultura católica, de la cual, aunque no se sea creyente $^{14}$, se aceptan y adoptan nociones, concepciones (por ejemplo, la moral, el derecho, el concepto de delito) y comportamientos. Estos hacen parte de un sistema de prácticas atado a las experiencias religiosas católicas, que se representan especialmente en las formas en que

12 El término performático se refiere a las características espectaculares o teatrales de un determinado suceso y es un falso análogo de performance y de performatividad, como lo aclara la directora-fundadora del Instituto Hemisférico de Performance y Política, Diana Taylor (2011, p. 24).

13 El ayuno y el autoentierro tienden a mantener a sus practicantes en la soledad en medio de la gente que los rodeaba y como prácticas ascéticas de aislamiento suponen «vivir en el desierto, pero hacia adentro» (Borja, 2008, p. 88).

14 Borja (2019) ha insistido en que el catolicismo, más que un sistema de creencias, es un sistema de prácticas que está atado a ese tipo de experiencia religiosa, por tanto, no se necesita que las personas crean para que haya cultura católica. 
se celebra la Semana Santa ${ }^{15}$, según asevera el historiador colombiano Jaime Borja (2019).

En estas protestas se apeló al imaginario católico tradicional de que la mortificación, el sufrimiento del dolor en el propio cuerpo, a semejanza del Cristo sufriente, cumple una función salvífica social; al mismo tiempo, es una lección moral que remite a virtudes como la resignación, la paciencia, la fortaleza y la templanza (Borja, 2008, p. 83). En concordancia con lo observado por Cruces (1998), estos rituales sacrificiales interpretados durante protestas campesinas o periurbanas, al transferirse al mundo político, capturan eficazmente la atención de la prensa y el público, porque consiguen «violar mediante una imagen inesperada el orden simbólico de la convivencia ordinaria» (31 y 73).

En los casos expuestos anteriormente, los manifestantes usaron sus cuerpos como fuente de significados inmediatos: la desatención, la invisibilidad, el abandono y los reiterados incumplimientos fueron traducidos en términos visuales, corporales, para que otros percibieran sin rodeos lo doloroso, lo cruento de las situaciones que vivían.

La prensa registró diversas valoraciones de estos eventos performáticos, que discurrieron entre bueno y malo, sano y enfermo, legal-ilegal, normal-anormal, bello-feo, absurdo-«cuerdo», repugnancia e indignación; a través de ellas, afloraron emociones y sentimientos tanto de quienes ejecutaron las acciones como de quienes las observaron (Figari, 2009, p. 133).

15 La Semana Santa, según Borja (2008), es muy importante, porque para el catolicismo barroco (que fue el que llegó a nuestros territorios) el cuerpo es malo por naturaleza, pero se puede salvar a punta de mucho sufrimiento. La pasión de Cristo es, entonces, el modelo a seguir, ya que encarna lo más corporal, que es el sufrimiento, el dolor y el hecho de ser martirizado, pero, al final, resucita. La cultura católica se obsesiona por el cuerpo doliente, el de la pasión de Cristo. Su crucifixión es un hecho fundamental para la religión católica, una de las escenas más representadas que «acrecienta la devoción y compunge las entrañas». En esa medida, su imitación (mortificaciones físicas individuales que ponían en juego los límites del cuerpo) fue concebida como útil para la redención colectiva (Foulard, 2017, p. 4). 
«El caso tiene entre escandalizados y conmovidos a los habitantes del barrio El Bosque de Usme, pues se trata de un grupo de personas que, ante la falta de respuesta de las autoridades a sus reclamos, encontraron que esta era la única forma en que podían hacerse escuchar». El escándalo deriva del significado que adoptan estos actos performáticos, ya que, como lo señala Diana Taylor (2011), son disruptivos, llamativos, inesperados y hasta chocantes y tienen una finalidad política más que artística o ritual. Son actos fuera de lugar que «trascienden a su contexto y nos obligan a repensar lo que vemos a la luz de lo que sabemos, y lo que sabemos en relación a lo que vemos» (Taylor, 2009, p. 23).

Los medios informaban que el alcalde pedía que abandonaran aquella «insólita protesta». ¿Acaso resultaba insólita por apelar a imágenes que poco o nada referían al problema que la había suscitado? Asimismo, se leía: «La noticia de la singular protesta ha corrido como reguero de pólvora entre los vecinos del barrio, quienes mantienen repleta la iglesia, en un constante ir y venir de curiosos». La singularidad de la protesta provenía del hecho de que fuesen vecinos de carne y hueso quienes mortificaban sus propios cuerpos, aun cuando la imagen de Cristo clavado en la cruz, bañado en su sangre, sea una las escenas más representadas y contribuya a acrecentar la devoción y a compungir las entrañas (Sigaut, 1992, p. 109).

Precisamente, algunos de los juicios emitidos en los periódicos que cubrieron estos eventos resaltaron las referencias religiosas ${ }^{16}$ : «Por medio de este suplicio, que recuerda la crucifixión utilizada por los romanos en tiempos de Jesucristo (...)», «Tal y como si quisieran revivir la pasión de Cristo, dos hombres se crucificaron (...)», «(...) se sepultaron vivos frente a una imagen de Jesús crucificado» $\mathrm{y}$ «La protesta es la continuación de ayunos de oración iniciados en esta localidad hace cuatro años,

16 Aunque sus contenidos no fuesen religiosos, lo que recuerda la sentencia de la literata francesa Camille Dumoulié (1996): «Vivimos en un mundo cada vez más religioso, pero que ha perdido el sentido de lo sagrado» (p. 29). 
para exigir a las autoridades de Bogotá, que mejoren sus condiciones de vida».

Otras fuentes indagadas subrayaron los riesgos que corría la salud de los manifestantes: «Sus rostros ya lucen demacrados y con notables síntomas de deshidratación debido a que solo se les suministra suero». «Estos líderes cívicos insisten en protestar a pesar del parte médico del doctor (...), quien ayer los examinó y dijo que algunos ya presentan preocupantes condiciones de salud». «Una líder comunal de 40 años no se ha atrevido a sepultarse, porque no quiere atentar contra su vida». «El alcalde de Bogotá, Antanas Mockus, se declaró conmovido por la protesta de estos líderes y dijo que, aunque los respeta, preferiría que no pusieran en riesgo su salud».

Unos artículos de prensa destacaron que eran protestas desesperadas por la vida, luchas de vida o muerte ante el abandono del Estado, tortuosos sistemas de protesta mediante los cuales se castigaba severamente a otros para que aprendieran o se presentaba el dolor como forma de pago («el escarmiento de esta impresionante escena»).

En medio del conflicto armado interno y de la globalización de la criminalización de la pobreza — particularmente urbana-, no faltaron las incriminaciones: «Las autoridades investigan denuncias de concejales que conocen la localidad sobre posibles manos oscuras en las protestas de los comunales que se enterraron vivos». Es importante anotar que Usme es uno de los sectores donde supuestamente hay milicias de las FARC.

Muy distintas fueron las valoraciones hechas por los propios manifestantes. Exaltaron el heroísmo: «arriesgan sus vidas por las miles de personas de su comunidad que esperan una respuesta de las autoridades a sus necesidades». «Sé que puedo morir, pero voy hasta el final, lo hago por mi familia y mi comunidad». «Vinieron a apoyar a su "padre y protector” [quien] antes de morir a manos de quienes lo tienen amenazado, prefiere irse de este mundo enterrado en medio de la comunidad 
que tanto lo quiere y con la cual tanto a luchado». De esta manera, develaron el significado otorgado por ellos a dichos actos: «el Gobierno solo ha hecho promesas de soluciones y firmar actas de compromiso que nunca cumple. Por eso, queremos con esta protesta enterrar las innumerables promesas de la administración actual». A su vez, insistieron en pedir no solo conmiseración, sino solidaridad efectiva: «le pido a los señores periodistas que no nos abandonen, que nos acompañen hasta el final, que den a conocer la situación que atraviesan».

Además de los sentidos de los rituales de sacrificio que se hicieron durante las tres acciones que se están analizando, el sentido cristiano de pago de la salvación, las lecciones de virtuosismo moral y las lecturas secularizadas del heroísmo civil — similares a las reseñadas por Cruces (1998, p. 49) - , es necesario explorar los usos políticos del cuerpo en medio de un ritual sacrificial que, en palabras de Alba Nubia Rodríguez, hace parte de una protesta social y que pretende transmitir mensajes que impacten y que, simbólicamente, puedan cuestionar o subvertir un orden establecido (Blair, 2004, p. 175). Para Reguillo (2009), «Al mostrar cuerpos dolientes/dolorosos, intervenidos, espinosos, se aspira a inscribir una huella en el sísmico proceso de reconocimiento político» (p. 37).

\section{Protestas sociales y cuerpos como hechos políticos}

Las protestas sociales son formas no convencionales de participación: acciones colectivas contenciosas que se ubican al margen de las demandas de participación electoral y de representación política, lo que no niega su carácter político, solo que este es no-institucional ${ }^{17}$. A estas

17 Según Claus Offe (1992), estas acciones no convencionales han sido calificadas por conservadores, desde mediados de los años setenta, como peligrosas, al estimarlas incompatibles con el mantenimiento del orden institucional de la política. Se presumía que ese modelo de actuación erosionaría la autoridad política y la incapacitaría para gobernar, si no se tomaban medidas eficaces para liberar a la economía de la intervención política detallada y para hacer inmunes a las élites políticas de las presiones de los ciudadanos. Entonces, se propuso como solución 
formas no convencionales de participación política se les exige que sus medios de acción sean aceptados explícitamente como legítimos y que sus objetivos sean reconocidos como válidos por la comunidad amplia (Offe, 1992, pp. 163-244). Por ello, para Cruces (1998), las luchas sociales también son pugnas por la definición de lo que es y no es político, y de la acción políticamente legítima (p. 30); ellas mismas son un campo de disputa, un texto que debe descifrarse.

Los objetivos de las protestas que estoy analizando son similares a los de muchas otras luchas sociales en las que se expresan, de manera colectiva y pública, necesidades y demandas, ante la inoperancia de mecanismos institucionales de participación y de diálogo con las autoridades que debieran atender tales peticiones y de cara a los incumplidos planes de desarrollo, proyectos prometidos en las campañas electorales y acuerdos firmados, en su mayoría, para poner fin a otras movilizaciones sociales.

Pero, si observamos cómo se articulan estas demandas a un vasto conjunto de motivaciones de protesta de pobladores de las llamadas periferias urbanas, encontramos que esos motivos develan malestares por la manera como se da la expansión urbana sobre los contornos rurales ${ }^{18}$.

redefinir, de manera restrictiva, lo que puede y debe ser considerado «político», $\mathrm{y}$, por ende, eliminar de la agenda gubernamental todas las cuestiones, prácticas, exigencias y responsabilidades «exteriores» a la esfera de la verdadera política (pp. 163-244). En Colombia, insistentemente, se exige a los protagonistas de las luchas sociales no «volver políticas» sus demandas. Por ejemplo, el 18 de marzo de 2019, el Comisionado de Paz aseveró, a propósito de la Minga Indígena: «Cada vez que se avanza en temas concretos, las comunidades quieren insistir en debates políticos... [Esos] se hacen en el Congreso de la República. No se puede confundir el espacio de la protesta social y de la manifestación sana, garantizada en la Constitución, con crear espacios políticos a partir de manifestaciones de las comunidades» (RCN Radio, 2019). Días antes, la ministra del Interior expresó que la minga podría estar politizada y que, en vez de hacer debates ideológicos, los indígenas debían puntualizar las propuestas que le tenían al Gobierno (Jerez, 13 de marzo de 2019).

18 David Harvey (2014) se pregunta si el veloz proceso de urbanización global acaecido en los últimos cien años ha contribuido al bienestar humano, si nos ha hecho mejores personas o si, gracias a él, nos hemos convertido en meras mónadas zarandeadas de un lado a otro en un océano urbano (p. 20). 
Este proceso no ha estado exento de violencias, toda vez que ha pretendido homogenizar las condiciones que permiten imponer la urbanidad -léase civilización, modernización, industrialización y progreso- sobre el espacio, los actores y las interacciones rurales, y tender mantos de olvido no solo sobre la rurbanización — la capacidad de modificar la urbe que tiene la presencia de prácticas, saberes, valores y objetos rurales en contextos urbanos (Micheletti y Letelier, 2016) - , sino acerca de la bidireccionalidad de ambos procesos (Cimadevilla, 2009), que implica complementariedad, contradicción e hibridación entre ellos (Méndez, 2005).

Comunicólogas y filósofos han llamado la atención sobre la naturalización ${ }^{19}$ del horror y la crueldad, de tal manera que, los espectáculos como estos rituales dolorosos con ribetes religiosos terminan siendo una representación del trato cruento hacia el otro de clase que se extiende y reproduce en la sociedad de nuestro tiempo (Boito y D'Amico, 2009, p. 16). Para Boito (2009), «La espectacularización profana del dolor o de situaciones humillantes produce una especie de plusvalor simbólico, ya que el otorgar jirones de intimidad se instaura como gesto gratuito (otra forma de despojo)» (p. 60).

Precisamente, esta manera de entender las acciones performáticas que autoinfligen dolor mientras señalan despojos y expoliaciones —en este caso, urbanas - abre una vía analítica que me permite aproximarme a la comprensión del sentido de los eventos descritos anteriormente: concebir

(...) el cuerpo como locus del conflicto, como testigo e imagen donde se imprimen las vivencias y horrores de una sociedad conflictuada (...) Un alto porcentaje de la población de los países latinoamericanos se instaura como cuerpos olvidados, que no son atendidos por las estrategias políticas de los gobiernos: cuerpos sin salud, sin educación y con escasa alimentación. (Boito y D’Amico, 2009, pp. 10 y 13)

19 Aunque, según Camille Dumoulié «hay ante cualquier acto de crueldad una especie de fascinación, a menudo horrorizada» (Boito, 2009, p. 62). 
En estos eventos performáticos que contienen violencias corporales autoinfligidas y se constituyen en actos de rebeldía, los cuerpos son individuales, pero «se usan como hecho político» al hacer que el propio cuerpo se vea atravesado por un interés colectivo de cambio (Pantoja, 2009, 17); así, al estar inmersos en eventos que suman demandas de otros, se convierten en cuerpos de protesta colectiva. Estas acciones performáticas tienen capacidad de movilizar y ejercer efectos en propios y ajenos a la protesta que se practica, gracias a la puesta en escena de los recursos expresivos que poseen los grupos implicados como gestos, dramatizaciones y rituales colectivos, en los cuales se ponen en juego procedimientos argumentativos y razones invocadas para lograr los fines propuestos a través de las protestas.

Ubicados en la sociedad del espectáculo, los manifestantes ponen en práctica una amplia gama de estilos comunicativos y técnicas de movilización que incluyen usos estratégicos de acciones corporales (...) que se basan en repertorios de protesta anteriores y los expanden [lo que permite hablar de «alfabetismo performático»]. Los actos [de protesta] implican configuraciones visuales, sonoras y de comportamiento que los manifestantes consideran eficaces a la hora de hacer reclamos, recuperar espacios y denunciar condiciones abusivas. (Fuentes, 2015, pp. 3 y 4)

El cubrimiento periodístico a los tres eventos que aquí se han expuesto, la atención prestada por las autoridades distritales y locales a los protagonistas y sus demandas, la inserción en la agenda pública distrital de algunos temas develados en estos actos, la curiosidad despertada en espectadores lejanos, entre los que se cuentan académicos y estudiosos de asuntos urbanos, es decir, la eficacia política de estas protestas, obedeció, en gran parte, al trabajo simbólico que adelantaron los implicados. Dicha labor apeló, de manera incisiva, a lo emotivo, a buscar, como lo sugiere el fotógrafo argentino Marcelo Brodsky (2009), «el sentimiento cómplice, que parte de la mirada, pero apunta a las entrañas» (p. 14). Estas protestas lograron un impacto comunicativo y un impacto material más allá de las mesas de diálogo-concertación 
y de las promesas, gracias a la obtención de respuestas a algunos de los reclamos colectivos.

Coincido con Rossana Reguillo (2009) cuando afirma que esta exposición performática de los «cuerpos y las corporalidades no busca la representación política de manera formal, sino el reconocimiento de su diversa manera de plantarse ante el mundo» (p. 51).

Los cuerpos y las corporalidades participantes en las tres acciones seleccionadas para este artículo fueron reconocidos como una manera particular de plantarse en el mundo y por haber constituido acciones políticas no violentas. Obtuvieron un reconocimiento ontológico y político de quien fue considerado como su adversario, el alcalde mayor de Bogotá, Antanas Mockus. Precisamente, por su calidad de antagonista y por su permanente reflexión sobre la política y lo político, su voz resulta autorizada para reconocer el valor de estas acciones performáticas ${ }^{20}$ como acciones políticas no violentas ${ }^{21}$. Para Mockus (2007), lo anterior se debe a que, dichas acciones se preocuparon por que los actos fueran comprendidos tanto por sus protagonistas como por sus destinatarios y terceros y por gobernarse mediante motivos (intereses, razones y emociones $^{22}$ ) y reglas (formales-legales e informales-morales, sociales, culturales); así mismo, dejaron clara la pretensión de que era una causa

20 Las incluye entre los ejemplos de su experiencia personal como destinatario de acciones políticas no violentas, cuando fue alcalde de Bogotá en los periodos 19951997 y 2001-2003 (Mockus, 2007, p. 247).

21 La acción política noviolenta (APNV) consiste en rechazar ofertas indignas, imponiendo pérdidas parciales (de recursos recuperables) al adversario, mediante la supresión o neutralización de sus fuentes de poder. Esta empieza donde se rompe la negociación, es una continuación del conflicto con el objetivo de mantener y defender una posición no negociable o difícilmente negociable. Huelgas, paros cívicos, campañas de desobediencia civil son acciones políticas noviolentas disruptivas (Cante, 2007, p. 220).

22 Como el miedo, la indignación por el daño que alguien inflige a otro, el resentimiento por el trato injusto recibido, la culpa por la propia acción incorrecta, entre otras (Mockus, 2007, p. 232). 
justa $^{23}$ de cara a un trasfondo normativo compartido con adversarios y terceros (pp. 231-240).

Se reafirma, entonces, el carácter político de estas acciones y la legitimidad de los medios de acción, aun cuando el recurso a la espectacularización del dolor de los cuerpos se aleje de la normatividad ya impuesta a la protesta.

\section{Protestas sociales ante la expansión urbana que asedia a sus entornos rurales}

\section{Usme: de centro doctrinero y despensa agrícola a Parque Minero Industrial ${ }^{24}$}

En su tesis de Maestría en Urbanismo de la Universidad Nacional, narra Marcos Cortés (2006) que, desde finales del siglo XVI, Usme era un centro doctrinero, junto con los pueblos de indios de Bosa, Fontibón, Engativá y Usaquén; después de su fundación en 1650 como San Pedro de Usme, se convirtió en el centro de una zona rural agrícola, que proveía de alimentos a Santafé (pp. 137-163). En 1911, se le otorgó la

23 La pretensión de verdad de la acción —otro pilar de la APNV, según Mockus (2007)— no estuvo presente en ninguno de los tres casos reseñados, como lo dejan ver otras protestas alrededor de los mismos motivos. Las demandas jurídicas y administrativas contra uno de los líderes de estas luchas y el escaso o nulo reconocimiento a la validez de esas acciones que hoy le otorgan otros líderes cívicos de la localidad, confirman la aseveración de Mockus de que actuar mintiendo o sobre la base de mentiras tiene costos muy altos (p. 230).

24 Los Parques Mineros Industriales (PMI), contenidos en del Plan de Ordenamiento Territorial de Bogotá (Decreto 190 de 2004), son zonas de explotación minera con manejo especial y concertado sobre la planificación de la actividad minera y de sus industrias derivadas, el control ambiental y la operación basada en principios de ecoeficiencia y usos futuros de los predios. Los tres PMI (Tunjuelo, Mochuelo y Usme) se localizan en la cuenca media del río Tunjuelo y son la fuente principal de extracción de piedra, arena, grava, arenisca y arcilla, materiales de construcción para infraestructura y actividad edificadora de la ciudad. En estos tres parques mineros se asientan las empresas cementeras Holcim, Cemex, Cementos Argos y la Ladrillera Santa Fe. Dentro de esa misma área se encuentra el relleno sanitario Doña Juana, en la localidad de Ciudad Bolívar (Martínez, 2007). 
categoría de municipio del departamento de Cundinamarca, en medio de conflictos y luchas entre colonos, arrendatarios y aparceros por la tenencia de la tierra.

En 1954, durante el gobierno de Gustavo Rojas Pinilla, se creó el Distrito Especial de Bogotá y Usme fue anexado junto con otros cinco municipios vecinos a la ciudad (Usaquén, Suba, Engativá, Fontibón y Bosa), lo que le permitió a la capital tener una extensa área en un momento de alto crecimiento de la población. No obstante, los antiguos pobladores de Usme siguieron considerándose pueblerinos, mientras Bogotá se veía como un centro alejado y distinto.

Figura 2. Bogotá D. C. con sus 20 localidades $^{25}$.

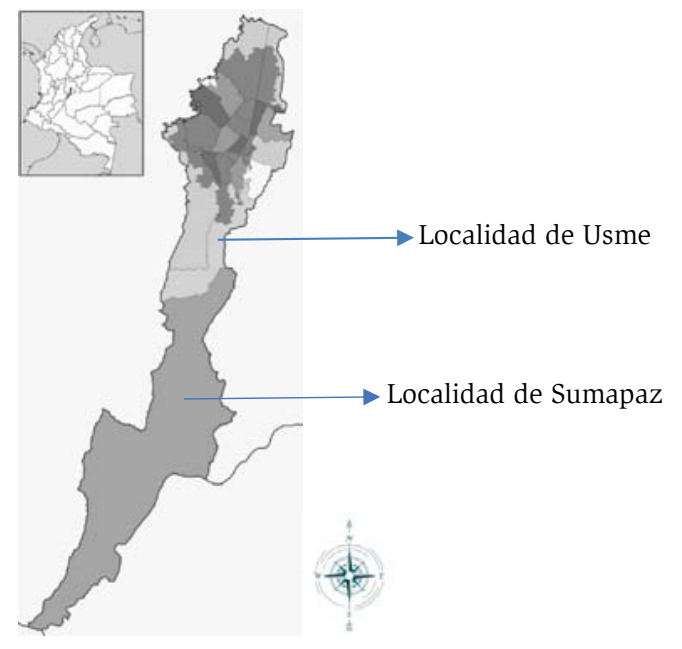

Fuente: Wikipedia.

Antes de dicha anexión, este municipio estaba conformado por cuatro manzanas y una placita central y por su límite occidental pasaba el río Tunjuelito, que desciende del Páramo de Sumapaz, localizado en la

25 El sombreado corresponde al área urbana del distrito. El 74\% restante de su superficie corresponde a suelo rural. 
parte sur del municipio; de los seis municipios anexados, este era el más distante de Bogotá. En 1953 había muy pocas urbanizaciones construidas y equipamientos entre los límites de Usme y Bogotá, y todos pertenecían a la capital: los barrios San Jorge, Tunjuelito y Santa Lucía, el antiguo Hospital Militar, el Hospital de San Carlos, los tanques de agua de Vitelma, el Velódromo Primero de Mayo y la Penitenciaría Central de la Picota, alrededor de los cuales había grandes vacíos urbanos; por entre ellos cruzaban la carretera a Chipaque y Villavicencio y la Autopista del Sur. Por las vías existentes, en ese momento, el municipio de Usme tenía más contacto con los Llanos Orientales que con Bogotá.

La expansión urbana, en aquel entonces, no ocurrió de manera uniforme en las tierras recién incorporadas, pues los sectores del norte presentaban mayor dinámica urbana, y solo décadas después se produjeron desarrollos urbanos en la zona rural de Usme.

Cortés (2006) devela que en los mapas de la época de la anexión no aparece dibujado Usme ni hay referencias a su existencia - a diferencia de los otros municipios agregados-, a pesar de su cercanía a la represa de La Regadera y a la hidroeléctrica de El Charquito. De igual modo, sobre las áreas anexadas del antiguo municipio de Usme no hubo ningún crecimiento urbano, en parte, por la presencia de los cerros del sur que, por su topografía, presentaban una limitación para tal fin (pp. 173177), y, en parte, por un proceso de parcelación de tierras que estaban destinadas a la producción agrícola para dar paso a la explotación artesanal de materiales para la construcción ${ }^{26}$. Esto derivó en que la zona se convirtiera en fuente importante de recursos para la urbanización de

26 Explotación minera que se mantiene hasta hoy y la comparte con las localidades que tienen asiento en los cerros orientales: San Cristóbal, Ciudad Bolívar, Rafael Uribe Uribe, Tunjuelito y Usaquén. 
Bogotá $^{27}$, mientras se transformaba radicalmente el paisaje del valle del río Tunjuelo y su cauce ${ }^{28}$.

Desde finales de los años cincuenta, Usme fue amasando una tradición carnicera $^{29}$ como resultado de la ocupación de su territorio más oriental por oleadas migratorias venidas de los Llanos Orientales ${ }^{30}$. Estas personas llegaron cargadas de oficios y saberes, sistemas de producción, redes culturales y comerciales, relacionados con la ganadería ${ }^{31}$ y acorde con la hegemonía que había alcanzado por aquel entonces la imposición del consumo de carne como un alimento predominante. Según afirma el historiador Alberto Flórez-Malagón (2008), además de hábito alimenticio, el consumo de carne era, sobre todo, «una práctica política referida a la imposición de valores y percepciones de unos grupos en menoscabo de otros», que contribuyó a la diferenciación social:

27 Para ampliar la información, véase la página oficial: http://www.usme.gov.co/content/historia-la-localidad-5a-usme

28 Estudios técnicos de la Secretaría de Ambiente revelaron que Holcim y dos empresas más «movieron» el río en 1968, 1974 y 1997, causando la pérdida de su cauce y del acuífero, por lo cual, en 2010, esta entidad distrital ordenó a la cementera suspender toda actividad extractiva por explotar de manera irregular el suelo y el agua del río Tunjuelito (El Espectador, 13 de julio de 2010).

29 Aún hoy, el expendio de carnes constituye una de las principales actividades económicas de los pobladores del antiguo casco urbano.

30 Los Llanos Orientales, en especial los departamentos de Casanare y Meta, han estado atravesados por todas las «violencias», desde la década de los cincuenta, ya sea como parte de la conquista militar de territorios o como parte de proyectos latifundistas de apropiación privada ilegal de tierras, con la consecuente y constante expulsión de poblaciones asentadas en la región (Arias, 2004, p. 111).

31 «Económicamente, desde la Colonia y durante buena parte de la historia nacional, pareciera que no hubiera más opciones para los Llanos Orientales sino el pastoreo de ganado vacuno para la producción de carne (...) el desarrollo particular de la ganadería en los Llanos siempre estuvo supeditado al comercio, el mercado y las comunicaciones con el altiplano, y la ganadería fue planteada desde sus inicios como una forma de colonización interna, de integrar e interconectar a la región con el mapa cultural, económico y político de la nación y de otras formas históricas de dominación política y territorial» (Arias, 2004, pp. 4-5). 
(...) se reforzaron los patrones patriarcales, así como las subordinaciones de clase expresadas a través de la vida cotidiana, en lo que se come o se puede comer (o comprar con los recursos disponibles); por ejemplo, se profundizaron las ideas de progreso que diferenciaron comensales civilizados de bárbaros, y así muchos otros aspectos de las relaciones sociales que se expresaron y reprodujeron en el acto de comer carne bovina (p. 439).

Esta es una curiosa diferenciación entre civilización y barbarie, sobre la cual también llama la atención la bióloga Brigitte Baptiste (2008): «(...) ese temible virus vacuno, acusado de la devastación de las selvas y páramos tropicales, es al mismo tiempo un indicador de "civilización” cuando se llega al juicio final sobre la calidad de un filete en la mesa» (p. 348).

Para Stefania Gallini (2008), en la atribución de ese alto valor material y simbólico otorgado a la carne bovina, los veterinarios, portadores de un saber experto, jugaron un papel preponderante en la primera mitad del siglo $\mathrm{xx}$, porque

se pronunciaban de manera influyente sobre muchos aspectos de la transformación final de un animal en carne (...) pero era en especial en su función de inspectores y clasificadores de las carnes destinadas al consumo que los veterinarios influían de una forma sutil en la determinación del tipo y desde luego la cantidad del consumo de carne. (p. 325)

Dichos profesionales continuaron desempeñando este papel hasta finales del siglo anterior, como se infiere de un documento de la Secretaría de Salud de Bogotá (ca. 1997):

El médico veterinario presente en el matadero y que representa a la autoridad sanitaria debe realizar la vigilancia sanitaria, asesorar en el buen manejo de [distintos] aspectos de saneamiento básico (...) prestar asesoría técnica al personal que labora en el matadero, vehículos y expendios mayoristas y minoristas, en aspectos relacionados con todos los procedimientos 
que tienen que ver con la manipulación, conservación, transporte de los productos cárnicos y principales zoonosis transmitidas por estas especies, órganos y desechos. En mataderos, el médico veterinario debe rotar en los diferentes turnos establecidos para el sacrificio de los animales. Además, debe verificar en forma diaria el registro de ingreso de animales, la procedencia de los mismos, decomisos y retenciones realizadas y su posterior desecho o eliminación; datos que serán incluidos en el informe trimestral que se remitirá a la dirección de salud pública. (pp. 3 y 6)

Entonces, la imposición hegemónica del consumo de carne bovina se acompañó de la promoción estatal de la higiene ${ }^{32}$, relacionada con la nutrición, la salubridad y el progreso. La ratificación de estos valores alimentó las normas urbanísticas ${ }^{33}$ y sanitarias en las que se basó la lucha contra los mataderos que emprendió la administración distrital a finales del siglo $\mathrm{xx}^{34} \mathrm{y}$ que obtuvo como respuesta, entre otras acciones, las ya descritas.

32 El mejoramiento de las condiciones sanitarias y el control higiénico sobre las reses y su reproducción se inició en el piedemonte metense antes que en otras zonas de la región. Villavicencio fue la población llanera donde se aplicaron con más rigor las medidas sanitarias, por ser el puerto de salida de las reses hacia Bogotá: por ejemplo, desde 1929, allí se inició la construcción de bañaderos oficiales para el ganado (Arias, 2004, p. 107).

33 Curiosamente, Robert Moses, calificado como el «maestro constructor» de Nueva York de mediados del siglo Xx, «diseñó una ciudad del siglo XXI a principios del XX. A cambio, destruyó buena parte de su tejido tradicional. Pisoteó barrios y libró a su antojo una guerra contra los espacios libres de autopistas» (Molins, 2019, p. 8) blandiendo «el hacha de carnicero» para poner en movimiento el espíritu de la modernidad, del progreso, según narra Marshal Berman (1991, p. 309), y así profundizar la dicotomía urbano-rural.

34 La lucha contra los mataderos en cuestión continúa: en 2018, el concejal liberal Álvaro Acevedo afirmó: «los mataderos de El Uval y de Usme llevan décadas ajustándose a la regulación existente en materia de sacrificio de ganado para la distribución de productos cárnicos, y han adaptado su infraestructura y procedimientos a la normatividad vigente; son cuantiosas las inversiones que los empresarios dueños de estos estos establecimientos han hecho como para arriesgarlas por el incumplimiento de las normas regulatorias de esta actividad impuestas por el Invima y el ICA» (Concejo de Bogotá, 13 de noviembre de 2018). 
Esta morosa acción del gobierno de la ciudad de Bogotá da cuenta del tardío proceso de incorporación urbana de Usme. Pero, cuando la ciudad llega a su borde suroriental e intenta imponer su orden ${ }^{35}$, lo hace de manera intempestiva y agresiva y los pobladores de esa frontera rechazan, como pueden, la pretensión urbana de fagocitar ese territorio periurbano resbaladizo, frágil, susceptible de intervenciones, para transformarlo, relocalizarlo, «correrlo de lugar», «incorporarlo» y consolidarlo ${ }^{36}$, dada su gran heterogeneidad en los usos del suelo, su inestabilidad en cuanto a la consolidación de redes sociales, su lejanía, invisibilidad y marginalidad.

Precisamente, para denunciar esa marginalidad, en 2002 se produjeron los autoentierros y las huelgas de hambre de doce moradores de Usme. Datos de ese mismo año, del Departamento Administrativo de Planeación Distrital, dan cuenta de la pobreza anidada en esa localidad, la más extensa —-después de Sumapaz-, que ocupa el 13,2\% del área total del Distrito, en contraste con su población en ese momento, que representaba tan solo el 3,91\% del total de la ciudad. Esta era la segunda localidad con más áreas rurales $(85 \%$ del total de su superficie) y de protección ( $46 \%$ de la superficie total); primordialmente, una

35 El miedo al desorden de la ciudad o, mejor dicho, el miedo a «la ciudad como desorden», en tanto espacio de confluencia de realidades complejas y conflictivas, el miedo a los impredecibles, discontinuos y contradictorios usos que provocan una difícil ordenación y fiscalización, marcó un punto de inflexión en la forma de organizar las relaciones espaciales dentro de las ciudades. El urbanismo fue una de las principales herramientas usadas para exorcizar la presencia de aquellas clases peligrosas que pueblan las urbes, que a menudo corren el riesgo de salvar la ciudad a costa de destruirla, como sostienen Marshal Berman, David Harvey y Jane Jacobs (Martínez, 2015, p. 85).

36 Esta forma de incorporación del borde suroriental a la ciudad se asemeja a la manera como la élite colonizadora bogotana, según describe al antropólogo Julio Arias (2004), pretendió imponer el progreso en los baldíos de los Llanos Orientales que les fueron adjudicados durante la segunda mitad del siglo XIX y las primeras décadas del xx: dominando la naturaleza y construyendo caminos. «La cuestión era hacer descender, como en una gesta heroica o una cruzada, la civilización del altiplano, la cual aludía a un modo de vida particular, a una forma de explotar la naturaleza, al orden que se quería implantar en medio del caos y del desorden que imperaba para ellos en los llanos» (p. 70). 
comunidad rural con escasa presencia industrial, pero con mucha actividad extractiva.

De 220 barrios registrados en 2002, 151 estaban legalizados por el $\mathrm{DAPD}^{37}$. Muchos eran producto de la invasión de antiguas zonas rurales de vocación forestal o de alta inestabilidad geotécnica, promovida por urbanizadores piratas; así, en los alrededores rurales de la nueva vía al Llano, fueron surgiendo asentamientos ilegales. Las coberturas de los servicios de acueducto y alcantarillado eran bajas, muchos barrios no consumían agua tratada -mientras parte de Bogotá aún se abastece de los embalses La Regadera, Chisacá y Los Tunjos ubicados en esa localidad- y en las veredas las aguas residuales eran vertidas a los cuerpos de agua, lo que generaba inmensos problemas de contaminación. El servicio de recolección de basuras se prestaba de manera muy irregular y los residuos se lanzaban a las quebradas; sin embargo, la mayoría de los barrios disponía de servicio de energía, mediante conexiones legales o ilegales.

Usme ocupaba el cuarto lugar entre las localidades que albergaban mayor población desplazada que arribaba a la ciudad, después de Ciudad Bolívar, Kennedy y Bosa; además, era una de las más afectadas por los fenómenos de desempleo y economía informal. Usme, Ciudad Bolívar, San Cristóbal y Santa Fe concentraban la mayor población en situación de pobreza y en miseria con respecto al total de su población.

Esta localidad presentaba riesgos biológicos y químicos por la presencia del relleno Sanitario de Doña Juana, así como por deslizamientos — por

37 Durante la administración del alcalde Jaime Castro (1992-1994), la conflictividad social en Usme se expresó con mayor intensidad después de que Planeación Distrital hiciera un llamado de atención a las JAL, por su empeño en invertir recursos en barrios ilegales, que sobrepasaban la mitad de los que entonces constituían la localidad (García, 1997, p. 115). Otra dificultad para invertir recursos locales era la falta de claridad sobre los límites entre localidades, por tanto, el desconocimiento de la pertenencia de aquellos barrios ubicados en esas zonas grises. Hasta 1993, se aclararon los linderos de la localidad de Usme. 
remoción de grandes masas de materiales-, inundación y contaminación de fuentes hídricas.

A pesar de este cúmulo de datos que manifiesta la precariedad en la que vivían los pobladores de esa localidad, el Plan de Ordenamiento Territorial adoptado en 2000 estableció que Usme sería el principal polo de desarrollo de la ciudad, donde se concentrarían grandes proyectos urbanísticos ${ }^{38}$, gracias a la disponibilidad de oferta de suelo (DAPD, 2004).

\section{Usme: tan lejos de la ciudad, pero tan útil a la metrópoli}

(...) cuando los núcleos urbanos se fueron desarrollando los problemas surgieron (...) para las basuras se consiguieron una o varias carretillas, volquetas o carros compactadores para transportarla a un sitio "lejos», donde nadie la viera y la sociedad se olvidó del problema; el daño tuvo que ser muy grande para que la comunidad lo sintiera, salieron moscas y ratones por todas partes, los olores llegaron a la ciudad y el paisaje se alteró; se acabaron los «lejos» y la basura llegó a la ciudad, la comunidad se percató del problema y empezaron a buscar soluciones para la disposición final

Misión Bogotá Siglo XXI (1991, p. 10).

La basura nunca se ha ido de la ciudad, solo se ha tirado hacia la periferia, y las soluciones para su disposición final no parecen haber sido las más adecuadas, dada la persistencia de problemas ambientales, sanitarios y administrativos ${ }^{39}$, las varias declaratorias de emergencia sanitaria y muchas protestas de los bogotanos. A través de estas no solo se

38 Que podrían atender parte de la demanda de vivienda del Distrito, según la Secretaría de Planeación: Ciudadela Nuevo Usme-Metrovivienda: 6000 viviendas y 24000 habitantes; Ciudad Nuevo Milenio-Colsubsidio: 7495 viviendas y 30000 habitantes; Operación Nuevo Usme: 57000 viviendas y 250000 habitantes.

39 Los botaderos oficiales a tajo abierto y con alta capacidad de contaminación de acuíferos, la proliferación de basureros en áreas verdes o lotes y el manejo inadecuado de desechos altamente tóxicos de origen industrial u hospitalario son, aún hoy, factores de contaminación de aguas, suelo y aire que constituyen un riesgo para la salud pública. 
denunciaron los impactos negativos sobre la salud y el medio ambiente derivados del ineficiente manejo de las basuras, sino que se exigió que el botadero final estuviese aún más «lejos» de su lugar de habitación.

En octubre de 1988 se cerró el basurero de Gibraltar (Kennedy) y comenzó a operar, en un lugar «lejano y despoblado» de la localidad de Ciudad Bolívar y vecino a Usme, el relleno sanitario Doña Juana, que había sido rechazado por los habitantes de esta localidad ${ }^{40}$ bajo la consigna «No queremos basuras, queremos escuelas y hospitales», en 1987, cuando se declaró emergencia sanitaria a fin de obtener empréstitos para comprar y adecuar el lote destinado al nuevo botadero.

Una década después (el 27 de septiembre de 1997), el relleno se derrumbó: un millón 200 mil toneladas de basura se precipitaron en minutos sobre el cauce del río Tunjuelo y tres localidades del sur de Bogotá resultaron afectadas por la exposición de desechos orgánicos, químicos e industriales, la emisión de lixiviados y gases y los olores nauseabundos. El 7 de octubre de ese año, habitantes de unos 20 barrios de Ciudad Bolívar, Usme y Tunjuelito, de la zona afectada por la avalancha del botadero, participaron de una manifestación para denunciar el problema de salud pública que los estaba afectando - y que aún hoy perturba parte del sector urbano de Usme- y para exigir a la administración distrital que declarara la emergencia sanitaria.

Como nos recuerda la socióloga Gabriela Vergara (2009), la basura ha sido relacionada no solo con la salubridad y la higiene, sino con la pobreza y la marginalidad. Desde mediados del siglo Xx se han intentado erradicar tanto los barrios miseria como los basurales, puesto que,

40 El 14 de julio de 1977, vecinos de los barrios El Cortijo, La Fiscala, Santa Marta y Barranquillita, de Usme, montaron una carpa, para hacer guardia día y noche, a la entrada de la finca de José Chávez, quien firmó un contrato con el gerente de la Edis para facilitarle un terreno para instalar un basurero para el sur y el occidente de la ciudad. Los vecinos dijeron que no permitirían el paso de camiones de la Edis y «si toca guerra, tocará» (El Tiempo, 29 de julio de 1977). 
como en un paralelo, los marginados de la sociedad se ubican en zonas cercanas a los basureros que se instalan a las afueras de las ciudades. «Sujetos y objetos dispuestos socioespacialmente parecen delatar los límites compatibles de la sociedad» (p. 37).

Además de estar en el área de influencia directa del receptor de las basuras de la ciudad (y, en algún momento se pensó que, de algunos municipios de Cundinamarca también ${ }^{41}$ ), Usme ha sido instituido parque minero industrial.

[En] Usme, lo que hace unas décadas eran frondosos bosques y pastizales serpenteados por el río Tunjuelo, donde sus habitantes hacían paseos de olla y se bañaban, hoy solo hay canteras desérticas explotadas a cielo abierto y un río agonizante contaminado por las cementeras y ladrilleras.

(...) cuando se desbordó el río Tunjuelo ${ }^{42}$ las cárcavas [dejadas por la minería] se llenaron de aguas putrefactas y se produjo una catástrofe ambiental. El río Tunjuelo es prácticamente el alcantarillado del sur y de Usme, entonces todo el sur de Bogotá se llenó de zancudos, ratas, moscas y luego declararon ese sector minero, y eso es lo que nosotros rechazamos. Además, los residentes del sur de la ciudad creen que la minería no les ha dejado ningún beneficio, pese a que el Estado recibe billonarias regalías. (Mundo Minero, 8 de abril de 2014)

41 El 11 de octubre de 2005, habitantes de los barrios La Aurora, de Usme, Mochuelo Alto y Bajo y las veredas Pasquilla y San Joaquín de Ciudad Bolívar, bloquearon la entrada del relleno sanitario Doña Juana, para impedir el ingreso de 400 toneladas de basura provenientes de municipios de Cundinamarca, ordenado por un funcionario distrital que fue desautorizado y despedido por el alcalde Lucho Garzón, y para advertir que no se vendería un pedazo más de tierra para ampliar el botadero.

42 El 9 de junio de 2002, a causa de intensas lluvias. Un mes después, unos 150 habitantes de la ronda del río Tunjuelito, liderados por el Comité de Damnificados del Tunjuelito, marcharon con antorchas y cruces para pedir a la administración distrital desecar las lagunas represadas en las canteras aledañas y poner en marcha un plan de manejo integral del río. Luego, enterraron las cruces en la ribera para significar posibles tragedias humanas, si no se atendían sus peticiones (Caracol Radio, 9 de junio de 2002). 
La explotación del Parque Minero Industrial ${ }^{43}$ de la Cuenca del río Tunjuelo ha transformado radicalmente el paisaje, ha causado desequilibrio ecológico -en época de lluvias fuertes, el río pierde su cauce en el área de explotación de gravas de diferentes empresas, el agua circula por las cárcavas, lo que genera malos olores y proliferación de insectos y afecta la población de los barrios circundantes - y ha aumentado los riesgos para la salud de los vecinos y de los trabajadores de las fábricas de ladrillos. No obstante, ha despertado en la población un movimiento de resistencia por los impactos ambientales que afectan el área.

Se evidencian, entonces, las que Eduard Soja (2014) denomina injusticias espaciales: poca inversión social en el cuidado del ambiente, en la dotación de bienes y servicios y en la ampliación del acceso a ellos, mientras que se deja en manos privadas —en grandes empresas, pequeños mineros artesanales, concesionarios de aseo urbano- el destino de los cerros orientales, las fuentes de agua, la salud de los pobladores y las vocaciones agrícolas.

Como en el caso de Córdoba, Argentina, estudiado por Espoz e Ibáñez (2009), el espacio social de Usme da cuenta de un ordenamiento espacial que segrega a los pobres en territorios alejados del centro urbano y oculta a la "ciudadanía» la realidad de la desigualdad que se materializa en cuerpos enfermos, sin salud, con hambre, pero, eso sí, acompañados de basuras y de extractivismo minero.

Las protestas sociales que he analizado en este artículo permiten reconstruir una trama conflictual en la que emergen cuerpos sin-trabajo,

43 La actividad minera informal también se adelanta en Usme, especialmente sobre los cerros orientales y el parque Entre Nubes, lo que causa alteraciones paisajísticas, modificación de la topografía, cambios de la dinámica hidrológica e hidrogeológica, contaminación atmosférica (por las industrias extractivas a cielo abierto y la falta de control de chimeneas de fábricas de ladrillos y centrales de mezcla) y de aguas subterráneas, y expone a la población circundante a riesgos de remoción en masa. 
sin-vivienda, sin-salud; cuerpos sin-representación, sin-alimentos; cuerpos invisibles.

Los sujetos de las autocrucifixiones nos dejaron saber que fueron despojados de su trabajo (por el cierre del matadero), del ingreso que les daba la posibilidad de re-producirse, y que también eran víctimas de la expoliación urbana. El sociólogo argentino Pedro Lisdero (2009) asevera que los-que-viven-del-trabajo solo poseen su cuerpo para intervenir en el proceso de producción, sus condiciones de reproducción son extremadamente precarias y su cuerpo se constituye también en la única herramienta de resistencia que anteponer.

Los protestatarios de Usme automortificaron sus cuerpos para develar el campo conflictual en el cual se inscribían sus luchas (actores, bienes y espacios) y para dar a conocer sus condiciones materiales. Con sus acciones performáticas y sus cuerpos en resistencia contribuyeron a recrear un espacio público donde pudieran ser vistos, «porque las leyes, la justicia, las protecciones laborales, las políticas públicas, más que sentar la base de un contrato mínimo, garantizan en muchas ocasiones la in-visibilidad de estos sujetos» (p. 114).

Entonces, los objetivos de estas acciones sociales colectivas merecen la aceptación social como válidos: fueron luchas contra la invisibilidad de sujetos, demandas, segregaciones, desigualdades, extrahecciones.

La pobreza duele. Las personas pobres sufren dolor físico como consecuencia de comer poco y trabajar muchas horas; dolor emocional a raíz de las humillaciones diarias que ocasiona la dependencia y la falta de poder $\mathrm{y}$ dolor moral por verse forzadas a hacer elecciones [que, en ocasiones, son más sacrificiales que otra cosa]; si se escuchara a los pobres... La voz de los pobres envía mensajes enfáticos que señalan el rumbo hacia el cambio de políticas (...) [Pero] las personas pobres dan cuenta de que sus interacciones con los representantes del Estado se ven teñidas de rudeza, humillación, abuso e indiferencia. (Narayan, 2000, pp. 3 y 5) 


\section{Cierre}

Carniceros y pobladores de la periferia urbano rural - sitio histórico donde residen los actores rurbanos, hoy espacio de antagonismos para llevar a cabo proyectos urbanísticos, mineros y de aseo metropolitanose levantaron contra la negación de su propia existencia y lucharon con su cuerpo, sus emociones y su subjetividad (Pleyers, 2018, p. 56) contra esa violencia sorda, convertida en «lenguaje epocal (...) esa violencia que es muchas, que se trasviste en múltiples ropajes y dilata su poder en todos los repliegues de lo social» (Reguillo, 2009, p. 39).

Esas luchas de las que he hablado a lo largo de este artículo participan también en la disputa por las memorias de la ciudad. En estas páginas he puesto en evidencia cómo una concepción de la ciudad como destino civilizatorio oblitera la pugna entre la ciudad y sus zonas periurbanas por los sentidos, prácticas y modos de habitar; oculta la conflictividad y la violencia que la expansión urbana genera sobre sus contornos rurales y fractura los modos de apropiación y producción de memorias colectivas sobre las maneras como lo urbano fagocita lo rural y desconoce la rurbanidad galopante en el corazón mismo de las urbes.

De acuerdo a lo anterior, podría afirmar — con base en la propuesta del comunicólogo argentino Gustavo Cimadevilla (2005) acerca de la existencia de una memoria legítima, oficial de lo urbano y una memoria rurbana, testimonial, subjetiva e inorgánica- que las protestas aquí observadas sacaron a la luz la pugna entre aquella memoria que ha permitido instalar una concepción dominante y legítima de urbanidad (como destino civilizatorio ligado a la valoración positiva de la técnica, el progreso y la modernidad) y otra memoria social rurbana asociada a la identidad de una determinada comunidad de actores (Kenbel y Cimadevilla, 2009, p. 18) que no se siente integrada ni aceptada ni escuchada por otros actores urbanitas. 


\section{Bibliografía}

Arias, Julio (2004). Ganadería, paisaje y región. Una historia ecológica y social de la Orinoquia colombiana. Bogotá: Instituto de Investigación de Recursos Biológicos Alexander von Humboldt.

Baptiste, Luis Guillermo (Brigitte) (2008). Ecología de los consumos de carne. En: Flórez-Malagón, Alberto (ed.), El poder de la carne. Historias de ganaderías en la primera mitad del siglo XX en Colombia, 338-367. Bogotá: Universidad Javeriana.

Berman, Marshal (1991). Todo lo sólido se desvanece en el aire. La experiencia de la modernidad. Bogotá: Siglo XXI.

Blair, Elsa (2004). Mucha sangre y poco sentido: la masacre. Por un análisis antropológico de la violencia. Boletín de Antropología de la Universidad de Antioquia, 18(35), 165-184.

Boito, María Eugenia y D’Amico, Marcelo (2009). De los estudios de acción colectiva a la sociología del cuerpo. En: Figari, Carlos y Scribano, Adrián (comp.), Cuerpo(s), subjetividad(es) y conflicto(s). Hacia una sociología de los cuerpos y las emociones desde Latinoamérica, 9-21. Buenos Aires: Fundación Centro de Integración, Comunicación, Cultura y Sociedad.

Boito, María Eugenia (2009). Imágenes crudas y mirada cruel sobre el 'otro de clase’ en Policías en Acción. En: Figari, Carlos y Scribano, Adrián (comp.), Cuerpo(s), subjetividad(es) y conflicto(s). Hacia una sociología de los cuerpos y las emociones desde Latinoamérica, 53-68. Buenos Aires: Fundación Centro de Integración, Comunicación, Cultura y Sociedad.

Borja, Jaime (2008). El cuerpo idealizado: la vida como una pasión (de Cristo). En: Hering, Max (ed.), Cuerpos anómalos. Bogotá: Universidad Nacional de Colombia.

Borja, Jaime (2019). Colombia sí es pasión, pero de Cristo [entrevista de Natalia Arbeláez, Marcela Becerra y Emilith Muñoz, 19 de abril]. Recuperado de: https://lasillavacia.com/silla-academica/universidad-los-andes-facultad-ciencias-sociales/colombia-si-pasion-cristo-71186.

Brodsky, Marcelo (2009). Políticas del cuerpo en América Latina. En: Brodosky, Marcelo y Pantoja, Julio (ed.), Body politics: políticas del cuerpo en la fotografía latinoamericana, 13-16. Buenos Aires: la Marca Editora. 
Cante, Freddy (2007). Acción política no violenta y negociación. En: Cante, Freddy (ed.), Poder social. Algunas posibilidades en Colombia, 210-227. Bogotá: Universidad del Rosario.

Cimadevilla, Gustavo (2009). De la dicotomía urbano-rural a la emergencia rurbana. Momentos y movimientos. En: Cimadevilla, Gustavo y Carniglia, Edgardo (coord.), Relatos sobre la rurbanidad, 163-186. Río Cuarto: Universidad Nacional de Río Cuarto.

Concejo de Bogotá (13 de noviembre de 2018). Los mataderos en Bogotá son base fundamental en el desarrollo de las zonas rurales del Distrito. Recuperado de: http://concejodebogota.gov.co/los-mataderos-en-bogota-sonbase-fundamental-en-el-desarrollo-de-las/cbogota/2018-11-13/071918.php

Cortés, Marco (2006). La anexión de los 6 municipios vecinos a Bogotá en 1954. Bogotá: Universidad Nacional de Colombia.

Cruces, Francisco (1998). El ritual de la protesta en las marchas urbanas. En: García Canclini, Néstor (coord.). La ciudad y los ciudadanos imaginados en los medios, 26-83. México: Universidad Autónoma Metropolitana, Iztapalapa y Grijalbo.

Departamento Administrativo de Planeación y Secretaría de Hacienda (2004). Recorriendo Usme. Diagnóstico físico y socioeconómico de las localidades de Bogotá. Bogotá: Alcaldía Mayor.

Dumoulié, Camille (1996). Nietzsche y Artaud: por una ética de la crueldad. México: Siglo XXI.

Espoz, María Belén e Ibáñez, Ileana Desirée (2009). Tramas hechas cuerpo(s). En: Figari, Carlos y Scribano, Adrián (comp.), Cuerpo(s), subjetividad(es) y conflicto(s). Hacia una sociología de los cuerpos y las emociones desde Latinoamérica, 69-81. Buenos Aires: Fundación Centro de Integración, Comunicación, Cultura y Sociedad.

Figari, Carlos Alberto (2009). Las emociones de lo abyecto: repugnancia e indignación. En: Figari, Carlos y Scribano, Adrián (comp.). Cuerpo(s), subjetividad(es) y conflicto(s). Hacia una sociología de los cuerpos y las emociones desde Latinoamérica, 131-139. Buenos Aires: Fundación Centro de Integración, Comunicación, Cultura y Sociedad. 
Flórez-Malagón, Alberto (2008). Dime qué comes y te diré quién eres. En: Flórez-Malagón, Alberto (ed.), El poder de la carne. Historias de ganaderías en la primera mitad del siglo Xx en Colombia, 368-439. Bogotá: Universidad Javeriana.

Foulard, Camille (2017). Hacia los límites del cuerpo: prácticas penitenciales de una mística católica en la Revolución mexicana. Trace, 72. Recuperado de: https://journals.openedition.org/trace/2487

Fuentes Marcela (2015). Performance, política y protesta. En: Diana Taylor y Marcos Steuernagel (ed.), ¿Qué son los estudios de performance? Duke University Press, HemiPress, Scalar.

Gallini, Stefania (2008). De razas y carne. Veterinarios y discursos expertos en la historia de la producción y consumo de carne en Colombia, 19001950. En: Flórez-Malagón, Alberto (ed.), El poder de la carne. Historias de ganaderías en la primera mitad del siglo XX en Colombia, 290-337. Bogotá: Universidad Javeriana.

García, Martha Cecilia (1997). Descentralización y movilización popular en Bogotá. En: García, Martha Cecilia y Zamudio, Vicente (comp.), Descentralización en Bogotá bajo la lupa (1992-1996). Bogotá: Cinep.

Harvey, David (2014). Ciudades rebeldes. Del derecho a la ciudad a la revolución urbana. Buenos Aires: Akal.

Jaramillo, José Manuel (2003). Figuras, usos y valores del agua en Bogotá. En: Revista Colombiana de Sociología, 1(VIII), 147-163.

Kenbel, Claudia y Cimadevilla, Gustavo (2009). La rurbanidad desde el enfoque de las memorias sociales. X Jornadas Argentinas de Estudios de Población. Asociación de Estudios de Población de la Argentina, San Fernando del Valle de Catamarca. Recuperado de: https://www.aacademica.org/000-058/98

Kowarick, Lucio (1991). Ciudad y ciudadanía. Análisis de metrópolis del subdesarrollo industrializado. En: Nueva Sociedad, 114, 84-93.

Linare, Cecilia y Tarquini, Soledad (2018). Enseñar la ciudad como territorio de memorias y relatos en disputa. La historia enseñada, 27, 71-81. 
Lisdero, Pedro (2009). Cuerpos recuperados y cuerpos en custodia. En: Figari, Carlos y Scribano, Adrián (comp.). Cuerpo(s), subjetividad(es) y conflicto(s). Hacia una sociología de los cuerpos y las emociones desde Latinoamérica, 101-118. Buenos Aires: Fundación Centro de Integración, Comunicación, Cultura y Sociedad.

Martínez, Ion (2015). Nuevas privatopías urbanas. Estrategias ciudadanistas del espacio público. Ciudades: Revista del Instituto Universitario de Urbanística de la Universidad de Valladolid, 18, 81-102.

Martínez, Yoholima (2007). Zonificación ambiental al interior de los parques mineros industriales. Recuperado de: http://oab.ambientebogota.gov.co/ descargar/3671/

Méndez, Javier (2005). Contradicción, complementariedad e hibridación en las relaciones entre lo rural y lo urbano. Revista Mad, 13, 1-25.

Micheletti, Stefano y Letelier, Francisco (2016). Aproximaciones para el estudio de las prácticas rurbanas en la ciudad intermedia chilena. Actividades de rebusque en Talca. Bifurcaciones, Revista de estudios culturales urbanos, 21, 1-13.

Misión Bogotá Siglo XXI (1991). Aseo y reciclaje. Bogotá: Alcaldía Mayor de Santa Fe de Bogotá.

Mockus, Antanas (2007). Pedagogía de la acción política no violenta. En: Cante, Freddy (ed.), Poder social. Algunas posibilidades en Colombia, 228-260. Bogotá: Universidad del Rosario.

Molins, Vincent (2019). Moses, el demonio que transformó Nueva York. Jot Down. Contemporary Cultural Magazine, 16.

Narayan, Deepa (2000). La voz de los pobres. ¿Hay alguien que nos escuche? Madrid: Mundi-Prensa y Banco Mundial.

Pantoja, Julio (2009). Fotografía y performance política. En: Brodosky, Marcelo y Pantoja, Julio (ed.), Body Politics: políticas del cuerpo en la fotografía latinoamericana, 17-19. Buenos Aires: la Marca Editora.

Offe, Claus (1992). Partidos políticos y nuevos movimientos sociales. Madrid: Sistema.

Pastor, Marialba (2004). Cuerpos sociales, cuerpos sacrificiales. México: FFyLUNAM/FCE. 
Pleyers, Geoffrey (2018). Movimientos sociales en el siglo XXI. Buenos Aires: Clacso.

Prieto Stambaugh, Antonio (2011). Corporalidades políticas: representación, frontera y sexualidad en el performance mexicano. En: Taylor, Diana y Fuentes, Diana (ed.), Estudios avanzados de performance, 607-628. México: FCE, Instituto Hemisférico de Performance y Política, New York University.

Reguillo, Rossana (2009). Sin cédula de identidad. Cuerpos elusivos en la encrucijada contemporánea. En: Brodosky, Marcelo y Pantoja, Julio (ed.), Body Politics: políticas del cuerpo en la fotografía latinoamericana, 33-58. Buenos Aires: la Marca Editora.

Restrepo, José Alejandro (2006). Cuerpo gramatical. Cuerpo, arte y violencia. Bogotá: Universidad de los Andes.

Rodrigo, María Luz y Val, Paula (2008). Miradas desde la historia: el cuerpo y lo corporal en la sociedad medieval. En: Gil, Marta y Cáceres, Juanjo (coord.), Cuerpos que hablan. Géneros, identidades y representaciones sociales. Madrid: Montesinos.

Secretaría Distrital de Salud de Bogotá (ca. 1997). Plantas de sacrificio de bovinos y porcinos. Recuperado de: https://cutt.ly/WrtrczR

Sigaut, Nelly (1992). La crucifixión en la pintura colonial. Relaciones. Estudios de historia y sociedad, 51, 101-141. Zamora: El Colegio de Michoacán.

Soja, Edward (2014). En busca de la justicia espacial. Valencia: Tirant Humanidades.

Taylor, Diana (2009). Cuerpos políticos. En: Brodosky, Marcelo y Pantoja, Julio (ed.), Body Politics: políticas del cuerpo en la fotografía latinoamericana, 21-31. Buenos Aires: la Marca Editora.

Taylor, Diana (2011). Performance, teoría y práctica. En: Taylor, Diana y Fuentes, Diana (ed.), Estudios avanzados de performance, 7-30. México: FCE, Instituto Hemisférico de Performance y Política, New York University.

Turner, Bryan (1989). El cuerpo y la sociedad. Exploraciones en teoría social. México: Fondo de Cultura Económica. 
Vergara, Gabriela (2009). Conflicto y emociones. Un retrato de la vergüenza en Simmel, Elías y Giddens como excusa para interpretar prácticas en contextos de expulsión. En: Figari, Carlos y Scribano, Adrián (comp.), Cuerpo(s), subjetividad(es) y conflicto(s). Hacia una sociología de los cuerpos y las emociones desde Latinoamérica, 35-52. Buenos Aires: Fundación Centro de Integración, Comunicación, Cultura y Sociedad.

\section{Prensa}

Caracol Radio (9 de junio de 2002).

Caracol Radio (27 de julio de 2010). «Desplazados protestan crucificados contra Acción Social». Recuperado de: http:// caracol.com.co/radio/2010/07/27/ bogota/1280218440_332692.html

CNN Español (4 de julio de 2017). «¿Por qué están en huelga de hambre casi 1500 guerrilleros presos de las FARC?». Recuperado de: https://cnnespanol. cnn.com/2017/07/04/por-que-estan-en-huelga-de-hambre-casi-1-500-guerrilleros-presos-de-las-farc

Coronell, Daniel (25 de julio de 2006). «Príncipes y mendigos».

Diario El Correo (14 de febrero de 2019). «Trabajadores de construcción civil se entierran y crucifican como protesta». Recuperado de: https:// diariocorreo.pe/edicion/huancayo/trabajadores-de-construccion-civil-se-entierran-y-crucifican-como-protesta-video-870572/

El Catolicismo (2017). «Cuerpos gramaticales en la Plaza de Bolívar». Recuperado de: http://elcatolicismo.com.co/es/noticias/12396-cuerpos-gramaticales-en-la-plaza-de-bolivar-.html.

El Catolicismo (22 de octubre de 2018). «El Señor del Monte de Galilea consagró su templo y altar». Recuperado de: http://elcatolicismo.com.co/es/ noticias/17006-el-senor-del-monte-de-galilea-consagro-su-templo-y-altar.html

El Colombiano (16 de junio de 2002). «Usme reclama las obras sepultando a sus líderes».

El Espectador (13 de julio de 2010). «Se confirma cierre de Holcim en Usme por manejo irregular del río Tunjuelo».

El País (14 de noviembre de 2013). «Aumentan los transportadores 'piratas' enterrados en protesta en Tuluá». 
El Tiempo (29 de julio de 1977).

El Tiempo (8 de julio de 1995).

El Tiempo (27 de febrero de 1996). «Crucificados en una iglesia».

El Tiempo (28 de febrero de 1996). «Matadero de Usme estará a prueba 15 días».

El Tiempo (29 de marzo de 1996). «El cierre del matadero generó bloqueo en Usme».

El Tiempo (3 de marzo de 1996). «El matadero no puede funcionar».

El Tiempo (12 de junio de 2002). «Se enterraron para protestar».

El Tiempo (13 de junio de 2002). «Una protesta con la tierra al cuello».

El Tiempo (14 de junio de 2002). «Euros para obras en Usme».

El Tiempo (25 de julio de 2006). «Parque de Miserias».

Insignares, Diana (1. ${ }^{\circ}$ de marzo de 1996). «La lucha de Usme por un matadero». El Tiempo.

Jerez, Daniel (13 de marzo de 2019). «Gobierno pide a indígenas del Cauca no acudir a las vías de hecho». RCN Radio. Recuperado de: https://www. rcnradio.com/colombia/sur/gobierno-pide-indigenas-del-cauca-no-acudirlas-vias-de-hecho

La Jornada (3 de octubre de 2008). «Se crucifican docentes en Morelos; manifestaciones en varios estados». Recuperado de: https:// www.jornada.com. $\mathrm{mx} / 2008 / 10 / 03 /$ index.php? section $=$ sociedad $\&$ article $=050 \mathrm{n} 1 \mathrm{soc}$

La Patria (24 de abril de 2012). «Médicos radicalizan medidas y deciden coserse los labios». Recuperado de: http://www. lapatriaenlinea.com/?t= medicos-radicalizan-medidas-y-deciden-coserse-los-labios\&nota $=104896$

La Prensa (19 de octubre de 2006). «Gobierno y Congreso buscan pacificar cárceles». Recuperado de: https://impresa.prensa.com/mundo/GobiernoCongreso-buscan-pacificar-carceles_0_1862063844.html

La Red 21 (13 de junio de 2002). «Se entierran y ayunan en protesta por la marginalidad». Recuperado de: http://www.lr21.com.uy/mundo/82657se-entierran-y-ayunan-en-protesta-por-la-marginalidad 
La Voz (19 de junio de 2002). «Enterrados vivos».

Mundo Minero (8 de abril de 2014). «La minería en el sur de Bogotá, tan grave como el desastre ambiental del Casanare». Recuperado de: http:// mundominero.com.co/la-mineria-en-el-sur-de-bogota-tan-grave-como-eldesastre-ambiental-del-casanare/

Periodista Digital (25 de octubre de 2007). «Las prostitutas de Bolivia se cosen los labios en protesta contra Evo Morales». Recuperado de: http:// blogs. periodistaDigital.com/personalidad.php/2007/10/25/ prostitutas_bolivia_ labios_evo_morales_0987

RCN Radio (13 de marzo de 2019). «Huila, el más afectado por desabastecimiento debido a minga indígena». Recuperado de: https://www.rcnradio. com/colombia/sur/huila-el-mas-afectado-por-desabastecimiento-debidola-minga-indigena

RCN Radio (13 de agosto de 2013). «Hombre se crucifica frente a embajada de EE.UU. por despidos masivos en General Motors». Recuperado de: https:// www.rcnradio.com/colombia/exempleado-se-crucifica-frente-embajadade-ee-uu-por-despidos-masivos-en-general-motor

Semana (9 de abril de 2009). «Profesor Moncayo no podrá crucificarse en la Plaza de Bolívar».

Sipse (6 de agosto de 2015). «La crucifixión como vía de protesta laboral». Recuperado de: https://Sipse.com/mundo/crucifixion-forma-protesta-laboral-paraguay-164408.html 


\section{Anexo 1}

Algunas protestas nacionales e internacionales que han recurrido a acciones de violencia autoinfligida

\begin{tabular}{|c|c|c|}
\hline \multicolumn{3}{|c|}{ Protestas nacionales } \\
\hline Fecha y lugar & Actores y motivos & Fuentes \\
\hline $\begin{array}{c}\text { Febrero de } \\
1996, \\
\text { Yumbo (Valle } \\
\text { del Cauca) }\end{array}$ & $\begin{array}{l}\text { Durante un paro de profesores, tres líderes } \\
\text { hicieron huelga de hambre y se crucificaron } \\
\text { a la vista del público. }\end{array}$ & BDLS Cinep \\
\hline $\begin{array}{c}\text { 1998-1999, } \\
\text { varias ciudades } \\
\text { del país }\end{array}$ & $\begin{array}{l}\text { Deudores del sistema UPAC hicieron largas } \\
\text { caminatas cargando pesadas cruces hasta } \\
\text { llegar a Bogotá y practicaron algunas cruci- } \\
\text { fixiones en plazas públicas durante el reco- } \\
\text { rrido, en protesta por la pérdida de sus vi- } \\
\text { viendas a causa del desmedido incremento } \\
\text { de las cuotas de pago. }\end{array}$ & BDLS Cinep \\
\hline $\begin{array}{l}\text { Julio de 2006, } \\
\text { localidad de } \\
\text { Bosa (Bogotá) }\end{array}$ & $\begin{array}{l}\text { Dos hombres y una mujer desplazados, de } \\
\text { los casi mil que permanecieron hacinados } \\
\text { en carpas en el parque central de Bosa, se } \\
\text { enterraron vivos durante dos días y otros se } \\
\text { colgaron de los postes para denunciar la fal- } \\
\text { ta de respuesta gubernamental a sus recla- } \\
\text { mos de techo, trabajo, salud y educación. }\end{array}$ & $\begin{array}{c}\text { (El Tiempo, } 25 \\
\text { de julio de 2006), } \\
\text { (Coronell, } 29 \text { de julio } \\
\text { de 2006) }\end{array}$ \\
\hline $\begin{array}{c}\text { Abril de } \\
\text { 2009, Melgar } \\
\text { (Tolima)-Bogotá }\end{array}$ & $\begin{array}{l}\text { El profesor Gustavo Moncayo recorrió casi } \\
100 \text { kilómetros con una cruz a cuestas, para } \\
\text { mostrar el calvario que vivía por el secues- } \\
\text { tro de su hijo por las FARC, desde hacía doce } \\
\text { años. Quiso crucificarse en la Plaza de Bolí- } \\
\text { var, pero la Secretaría de Gobierno Distrital } \\
\text { no lo autorizó. }\end{array}$ & $\begin{array}{l}\text { (Semana, } 9 \text { de abril } \\
\text { de 2009) }\end{array}$ \\
\hline
\end{tabular}




\section{Protestas nacionales}

\section{Fecha y lugar}

Actores y motivos

\section{Fuentes}

Cuatro de los 36 desplazados por la violencia que se concentraron ante la sede de la

Julio de 2010, localidad de Puente Aranda (Bogotá)

Agosto de 2013, Bogotá

Unidad de Atención y Orientación al Desplazado en Puente Aranda se ataron de pies y manos a estacas y se cosieron los labios para exigir al Gobierno que respondiera por los subsidios de vivienda y los recursos que les prometió para adelantar sus proyectos productivos.

Un extrabajador de la empresa General Motors se crucificó frente a la Embajada de Estados Unidos para protestar por el despido masivo de empleados afectados por enfermedades laborales. Él y siete compañeros llevaban 743 días viviendo en un cambuche frente a esa embajada exigiendo su reintegro y el reconocimiento de sus derechos laborales.

Noviembre de 2013, TuluáAndalucía (Valle del Cauca)

Junio-julio de 2017, varias ciudades del país
Tres conductores de vehículos que cubrían la ruta Tuluá-Andalucía se enterraron en el tar contra los operativos adelantados por la Policía Vial contra el transporte pirata.

1420 presos políticos de las FARC recluidos en distintas cárceles se declararon en huelga de hambre y 44 de ellos se cosieron los labios para protestar por la débil gestión del Gobierno frente a las amnistías a los guerrilleros encarcelados. separador vial de esa autopista para protes-
(Caracol Radio, 27

de julio de 2010) de agosto de 2013)

(El País, 14 de noviembre de 2013)

(CNN Español, 4 de julio de 2017) 


\section{Protestas nacionales}

\section{Fecha y lugar}

de julio de

2017, Bogotá

Actores y motivos

\section{Fuentes}

En la Plaza de Bolívar de Bogotá, 30 perso-

nas sembraron sus cuerpos exigiendo justicia para las personas desaparecidas y ejecutadas. El evento fue celebrado en conmemoración de los nueve años de la desaparición y ejecución extrajudicial de Fair Leonardo Porras Bernal, joven de Soacha (Cundinamarca), quien fue presentado como «falso positivo» en Ocaña (Norte de Santander).

\begin{tabular}{|c|c|c|}
\hline \multicolumn{3}{|c|}{ Protestas internacionales } \\
\hline Fecha y lugar & Actores y motivos & Fuentes \\
\hline $\begin{array}{c}\text { Octubre de } \\
2006, \\
\text { Cochabamba y } \\
\text { La Paz, Bolivia }\end{array}$ & $\begin{array}{l}\text { Durante una huelga nacional de reclusos } \\
\text { para pedir la flexibilización de penas y pro- } \\
\text { cedimientos establecidos por la ley antinar- } \\
\text { cóticos, algunos presos en Cochabamba se } \\
\text { cosieron los labios y se hicieron sujetar con } \\
\text { cuerdas a cruces de madera; así mismo, en La } \\
\text { Paz, otros se hicieron enterrar hasta el cuello. }\end{array}$ & $\begin{array}{l}\text { (La Prensa, } 19 \text { de } \\
\text { octubre de 2006) }\end{array}$ \\
\hline $\begin{array}{c}\text { Octubre de } \\
\text { 2007, El Alto, } \\
\text { Bolivia }\end{array}$ & $\begin{array}{l}\text { Más de medio centenar de prostitutas ocupó } \\
\text { un centro médico e inició una huelga de ham- } \\
\text { bre. Algunas se cosieron los labios y amena- } \\
\text { zaron con enterrarse vivas para protestar } \\
\text { contra el Gobierno de Evo Morales, porque } \\
\text { no sancionó a quienes argumentaron que los } \\
\text { bares y burdeles eran nidos de delincuencia y } \\
\text { los quemaron y destruyeron. }\end{array}$ & $\begin{array}{c}\text { (Periodista Digital, } 25 \\
\text { de octubre de 2007) }\end{array}$ \\
\hline $\begin{array}{c}\text { Octubre de } \\
2008, \\
\text { Cuernavaca, } \\
\text { México }\end{array}$ & $\begin{array}{l}\text { Seis profesores se crucificaron ante el Pala- } \\
\text { cio de Gobierno en Cuernavaca, Morelos, } \\
\text { en repudio a la Alianza por la Calidad de } \\
\text { la Educación (ACE), porque eliminaría las } \\
\text { prestaciones magisteriales, y para pedir } \\
\text { la instalación de mesas de diálogo en pro de } \\
\text { una solución al conflicto. }\end{array}$ & $\begin{array}{l}\text { (La Jornada, } 3 \text { de } \\
\text { octubre de 2008) }\end{array}$ \\
\hline
\end{tabular}

(El Catolicismo, 2017) 


\section{Protestas internacionales}

\begin{tabular}{|c|c|c|}
\hline Fecha y lugar & Actores y motivos & Fuentes \\
\hline $\begin{array}{c}\text { Abril de 2012, } \\
\text { Santa Cruz, } \\
\text { Bolivia }\end{array}$ & $\begin{array}{l}\text { Médicos se cosieron los labios ante la in- } \\
\text { transigencia del Gobierno para solucionar el } \\
\text { conflicto que causó un decreto supremo que } \\
\text { restableció las ocho horas por jornada en el } \\
\text { sector de la salud. }\end{array}$ & $\begin{array}{c}\text { (La Patria, } 24 \\
\text { de abril de 2012) }\end{array}$ \\
\hline $\begin{array}{c}\text { Septiembre de } \\
\text { 2014, Asunción, } \\
\text { Paraguay }\end{array}$ & $\begin{array}{l}\text { Tres choferes de una empresa de transportes } \\
\text { se crucificaron para reclamar a sus patronos } \\
\text { el cumplimiento de leyes laborales y garan- } \\
\text { tías de seguridad social. }\end{array}$ & $\begin{array}{l}\text { (Notimérica, } 11 \text { de } \\
\text { septiembre de 2014) }\end{array}$ \\
\hline $\begin{array}{l}\text { Septiembre de } \\
\text { 2015, Asunción, } \\
\text { Paraguay }\end{array}$ & $\begin{array}{l}\text { Decenas de exempleados de una empre- } \\
\text { sa de transportes y de la hidroeléctrica de } \\
\text { Itaipú se crucificaron y algunos sellaron sus } \\
\text { bocas con gruesos clavos curvos. Los con- } \\
\text { ductores protestaban por el despido de } 51 \text { de } \\
\text { ellos después de notificar a la empresa que } \\
\text { habían creado un sindicato. Los represen- } \\
\text { tantes de la Coordinadora de Trabajadores } \\
\text { de Itaipú, por segunda vez en seis meses, } \\
\text { se crucificaron para exigir el pago retroacti- } \\
\text { vo de unos derechos laborales consignados } \\
\text { en un convenio firmado entre los gobiernos } \\
\text { de Paraguay y Brasil. }\end{array}$ & $\begin{array}{c}\text { (Sipse, } 6 \text { de agosto } \\
\text { de } 2015 \text { ) }\end{array}$ \\
\hline $\begin{array}{l}\text { Febrero de } \\
\text { 2019, Huanca- } \\
\text { yo, Perú }\end{array}$ & $\begin{array}{l}\text { Trabajadores de Construcción Civil que ade- } \\
\text { lantaban la obra del hospital El Carmen se } \\
\text { enterraron y crucificaron para denunciar } \\
\text { una disposición del gobernador regional: } \\
\text { despedir a todo el personal para que él pu- } \\
\text { diera disponer de los puestos laborales. }\end{array}$ & $\begin{array}{l}\text { (Diario El Correo, } 14 \\
\text { de febrero de 2019) }\end{array}$ \\
\hline
\end{tabular}

